\title{
Genetic Markers Associated with Milk Production Traits in Dairy Cattle
}

\author{
Yulin Ma ${ }^{1,+}$, Muhammad Zahoor Khan ${ }^{1,2,+}{ }^{+}$Jianxin Xiao ${ }^{1}{ }^{\mathbb{D}}$, Gibson Maswayi Alugongo ${ }^{1}, \mathrm{Xu}_{\text {Chen }}{ }^{1}$, \\ Tianyu Chen ${ }^{1}$, Shuai Liu ${ }^{1}\left(\mathbb{D}\right.$, Zhiyuan He ${ }^{1}$, Jingjun Wang ${ }^{1}{ }^{1}$, Muhammad Kamal Shah ${ }^{2}$ and Zhijun Cao ${ }^{1, *(D)}$ \\ 1 State Key Laboratory of Animal Nutrition, Beijing Engineering Technology Research Center of Raw Milk \\ Quality and Safety Control, College of Animal Science and Technology, China Agricultural University, \\ Beijing 100193, China; bs20193040395@cau.edu.cn (Y.M.); zahoorcau@cau.edu.cn (M.Z.K.); \\ xiaojianxin-dairy@cau.edu.cn (J.X.); 1b2020270153@cau.edu.cn (G.M.A.); sy20193040671@cau.edu.cn (X.C.); \\ chentianyu@cau.edu.cn (T.C.); liushuaicau@cau.edu.cn (S.L.); hezhiyuan@cau.edu.cn (Z.H.); \\ wangjingjun@cau.edu.cn (J.W.) \\ 2 Faculty of Veterinary and Animal Sciences, The University of Agriculture, Dera Ismail Khan 29220, Pakistan; \\ kamalshah@gu.edu.pk \\ * Correspondence: caozhijun@cau.edu.cn; Tel.: +86-010-6273-3746 \\ + These two authors equally contributed to this work.
}

Citation: Ma, Y.; Khan, M.Z.; Xiao, J.; Alugongo, G.M.; Chen, X.; Chen, T.; Liu, S.; He, Z.; Wang, J.; Shah, M.K.; et al. Genetic Markers Associated with Milk Production Traits in Dairy Cattle. Agriculture 2021, 11, 1018. https://doi.org/10.3390/ agriculture11101018

Academic Editor: Karina Pierce

Received: 24 August 2021

Accepted: 14 October 2021

Published: 18 October 2021

Publisher's Note: MDPI stays neutral with regard to jurisdictional claims in published maps and institutional affiliations.

Copyright: (C) 2021 by the authors Licensee MDPI, Basel, Switzerland. This article is an open access article distributed under the terms and conditions of the Creative Commons Attribution (CC BY) license (https:// creativecommons.org/licenses/by/ $4.0 /)$.

\begin{abstract}
Increasing milk production is one of the key concerns in animal production. Traditional breeding has gotten limited achievement in the improvement of milk production because of its moderate heritability. Milk production traits are controlled by many genes. Thus, identifying candidate genes associated with milk production traits may provide information that can be used to enhance the accuracy of animal selection for moderately heritable traits like milk production. The genomic selection can enhance the accuracy and intensity of selection and shortening the generation interval. The genetic progress of economically important traits can be doubled with the accuracy of selection and shortening of generation interval. Genome-wide association studies (GWAS) have made possible the screening of several single nucleotide polymorphisms (SNPs) in genes associated with milk production traits in dairy cattle. In addition, RNA-sequencing is another well-established tool used to identify genes associated with milk production in dairy cattle. Although it has been widely accepted that these three methods (GWAS, RNA-seq and DNA sequencing) are considered the first step in the screening of genes, however, the outcomes from GWAS, DNA-sequencing and RNA-seq still need further verification for the establishment of bonafide causal variants via genetic replication as well as functional validation. In the current review, we have highlighted genetic markers identified (2010-to date) for their associations with milk production traits in dairy cattle. The information regarding candidate genes associated with milk production traits provided in the current review could be helpful to select the potential genetic markers for the genetic improvement of milk production traits in dairy cattle.
\end{abstract}

Keywords: review; milk production; dairy cattle; RNA-seq; GWAS; DNA sequencing; polymorphism; genetic markers

\section{Introduction}

Milk production traits have fundamental roles in dairy development and related economy [1,2]. The bovine milk production traits such as milk yield, fat content, protein content and somatic cell score (SCS) are the essential economic traits used to measure the quality of milk [3,4]. Traditional breeding methods have achieved considerable success in many economic traits; however, milk production having moderate heritability, the gains was not fruitful with common traditional breeding [5]. Being a polygenetic trait, milk production is controlled by many genes [6,7]. Thus exploring the genetic changes underlying preferred phenotypes is the target of today's animal producers. It has been well-established that the 
production of milk can be enhanced through genetic marker-assisted selection [8,9]. Various approaches such as mapping of quantitative trait loci (QTL), genome-wide association study (GWAS), RNA-sequencing, whole-genome sequencing and candidate gene analysis have been used to screen out the causal genes or their mutations associated with milk production traits [10-14]. So far, many candidate genes or polymorphisms within these genes have been identified that have a positive correlation with milk production traits in dairy cattle $[1,15,16]$.

Through genomic selection, we can identify genetically superior animals at a very early age. The DNA-tested animals can get accurate genomically enhanced breeding values before they enter into sexual maturity. In addition, because of the heavier use of young, genetically superior males and females in genomic selection, the generation interval can be decreased. The intensity of selection can be enhanced because the breeders use genomic testing to identify a larger group of potentially superior animals. Altogether by enhancing the accuracy and intensity of selection and decreasing the generation interval, the rate of genetic progress for economically essential dairy traits can be almost doubled. Keeping in view the importance of genomic selection, the current review was designed to highlight the possible development on genetic markers associated with milk production traits in dairy cattle.

\section{Materials and Methods}

The data were collected through authentic sources, such as PubMed, ScienceDirect, Web of Science, SpringerLink, Scopus, and Google Scholar, using polymorphism, genetic markers, GWAS, RNA-seq, DNA-sequencing (Whole genome sequencing) and dairy cattle milk production traits as major keywords. All the published studies that have discussed the polymorphisms in genes and their association with milk production traits in dairy cattle were included in the current review. Moreover, we also included the published studies that reported the direct effect of genes on milk production traits in dairy cattle. Similarly, all the published articles in the English language and scientific citation index (SCI) peerreviewed journals were incorporated for discussion in the current review. Furthermore, we considered articles (approximately 96\%) published from 2010 onward in a present review article. Those genes from RNA-seq data associated with milk production traits and differentially expressed $(p<0.05, Q<0.05)$ or validated through qPCR, were selected in the current review article. The present review article included all the polymorphisms in genes reported through GWAS or functional validation that were significantly associated with milk production traits in dairy cattle. Conversely, we excluded the data that was available in the form of conference papers, books, book chapters, thesis data and unpublished findings.

\section{Genome-Wide Association Studies (GWAS) for Screening of Genetic Markers for Milk Production in Dairy Cattle}

Genome-wide association studies have been extensively practiced to screen the polymorphism in genes associated with milk production traits in dairy cattle [17-20]. The detail of genes and their SNPs has been summarized in Table 1. Recently, Jiang et al. reported eight genes (ACSBG2, NLK, UGDH, MAP3K1, TBC1D1, RETSAT, CENPE, and FCGR2B) associated with milk production traits in 769 Chinese Holstein cows through GWAS study (Table 1) [21]. Consistently, another study documented 22 genes (SLC37A1, ALPL, MGST1, ABCG2, MEPE, PKD2, HERC3, SEPSECS, SEL1L3, DHX15, CSN1S1, CSN1S2, CSN2, CSN3, PAEP, DGAT1, RECQL4, MROH1, BOP1, ANKH, AGPAT6 and PICALM) through GWAS study which were linked to milk protein in 8080 cows (2967 Montbéliarde, 2737 Normande, and 2306 Holstein) [22]. Iung et al. performed the weighted single-step genomic BLUP (WssGBLUP) method to identify genomic regions correlated with milk production traits in the Brazilian Holstein cattle population. For this purpose 75,228 phenotypic records from 5981 cows were obtained, while genotypic data of 56,256 SNPs from 1067 cows were selected for the GWAS study [23]. Finally, ABCG2, DGAT1, MGST1, SLC37A1, LTBP1, $L R R C 19, P D E 9 A$, and PAEP genes were found to be link with milk production phenotypic traits in the Brazilian Holstein cattle population [23]. By using the GWAS study, 
the genomic regions on BTA14 were explored for their association with milk production traits in Holstein's population (21,068 cows) selected from four different countries (Belgium, The Netherlands, Great Britain and Denmark) [24]. Through weighted single-step genomic BLUP approach, they reported several genes (MIR2308, LOC104973955, CYHR1, ZNF34, FOXH1, COMMD5, TONSL, PPP1R16A, CPSF1, RPL8, DGAT1, ARHGAP39, GPT, $L R R C 14$, and GML) distributed on BTA14 that were significantly correlated with milk yield (Table 2). Many of the genes such as TONSL, PPP1R16A, FOXH1, ARHGAP39, CYHR1 and ARHGAP39 have also been documented by previous studies for their association with milk production traits [25-27]. Furthermore, Nayeri et al. documented that SNPs in CPSF1, DGAT1, TONSL, CYHR1, FOXH1 and PPP1R16A were associated with milk yield in Canadian Holsteins [12,25]. Buitenhuis et al. [25] also showed that $G M L$ is significantly linked to milk fat and protein in dairy cattle. Interestingly, Poulsen et al. documented several genes such as ALG3, B3GALNT2, LOC520336, PIGV, MAN1C1, ST6GALNAC6, GLT6D1, GALNT14, GALNT17, COLGALT2, LFNG and SIGLEC by performing GWAS analysis in Danish Jersey and Holsteins [28].

By using the GWAS study, Ariyarathne et al. [29] reported key genetic markers that were associated with FP (MGST1, DGAT1, CEBPD, SLC52A2, GPAT4, and ACOX3), PP (CSN1S1, GOSR2, HERC6, and IGF1R) and milk urea (GMDS, E2F7, SIAH1, SLC24A4, $L G M N$, and ASS1) of Holstein Friesian, Jersey or crossbred cows in New Zealand [29]. Similarly, Bouwman et al. documented candidate genes (ABCG2, DGAT1 SCD1, ACLY, SREBF1, STAT5A, GH, PPARGC1A, ACSS2, AGPAT6 and FASN) that were significantly correlated with milk fatty acid traits in lactating Dutch Holstein Friesian at Netherlands [17]. Li et al. conducted a GWAS study for milk fatty acid traits in 784 Chinese Holstein cows and found that polymorphisms in some key genes showed a link with milk fatty acid traits [30]. Although we highlighted several genes documented through the GWAS study, however, the functional validation of these genes is highly warranted before adding them as genetic markers for milk improvement in dairy cattle breeding.

Table 1. GWAS study for screening genetic markers associated with milk production trait.

\begin{tabular}{|c|c|c|c|c|}
\hline SNP (Gene) & Production Traits & $\begin{array}{l}\text { Breed and Phenotypic Traits and Method Used for } \\
\text { Association }\end{array}$ & Country & Author \\
\hline rs381714237 (FCGR2B) & MY, PY and PP & Chinese Holstein & China & {$[21]$} \\
\hline $\begin{array}{l}\text { ss2137349053 (CENPE) } \\
\text { rs385060942 } \\
\text { ss2137349051 } \\
\text { rs453960300 } \\
\text { rs378415122 }\end{array}$ & MY, FY and PY & Chinese Holstein & China & [21] \\
\hline rs134985825 (RETSAT) & MY, FY, PP, PY & Chinese Holstein & China & {$[21]$} \\
\hline rs377943075 (ACSBG2) & Milk FY, PP & Chinese Holstein & China & {$[21]$} \\
\hline rs136639319 (TBC1D1) & Milk FP and PP & Chinese Holstein & China & {$[21]$} \\
\hline $\begin{array}{l}\text { rs379188781 (NLK) } \\
\text { rs134444531 }\end{array}$ & Milk PY and PP & Chinese Holstein & China & [21] \\
\hline ss2137349058 (MAP3K1) & MY, FY and PY & Chinese Holstein & China & {$[21]$} \\
\hline ss2019489562 (UGDH) & MY & Chinese Holstein & China & {$[21]$} \\
\hline BovineHD2400007916 (CDH2) & Milk FP & $\begin{array}{l}\text { Dual-purpose Xinjiang Brown cattle } \\
2410 \text { individuals with } 6811 \text { reproductive records and } \\
5441 \text { milk records }\end{array}$ & China & {$[31]$} \\
\hline BTB-01731924 (GABRG2) & Milk PY & Dual-purpose Xinjiang Brown cattle & China & [31] \\
\hline rs136947640 (exon10) (FASN) & Milk fat traits & Dual-purpose Xinjiang Brown cattle & China & [31] \\
\hline rs41919985 (Exon-39) (A2266T) & Milk fat traits & Dual-purpose Xinjiang Brown cattle & China & [31] \\
\hline
\end{tabular}


Table 1. Cont.

\begin{tabular}{|c|c|c|c|c|}
\hline SNP (Gene) & Production Traits & Breed and Phenotypic Traits and Method Used for Association & Country & Author \\
\hline $\begin{array}{l}\text { ARS-BFGL-NGS-24998 (SAA3) } \\
\text { UA-IFASA-8605 (SAA3) } \\
\text { BFGL-NGS-119420 (TRIB3) } \\
\text { ARS-BFGL-NGS-69013 (SESN2) } \\
\text { BTA-31250-no-rs (SESN2) } \\
\text { Hapmap53714-rs29017586 (CHAC1) } \\
\text { ARS-BFGL-NGS-5790 (NR4A1) } \\
\text { UA-IFASA-8605 (SAA1) } \\
\text { UA-IFASA-8605 (M-SAA3.2) } \\
\text { BTA-68781-no-rs (HIST1H2AC) } \\
\text { BTB-00411816 (THBS4) } \\
\text { ARS-BFGL-NGS-85980 (FAM71A) } \\
\text { ARS-BFGL-NGS-72191(H4) } \\
\text { ARS-BFGL-NGS-29557 (PTHLH) } \\
\text { ARS-BFGL-NGS-81082(ARID1B) } \\
\text { ARS-BFGL-NGS-72191 (BoLA-DQB) } \\
\text { ARS-BFGL-NGS-107749 (CDH16) } \\
\text { ARS-BFGL-NGS-29490 (VEGFA) } \\
\text { ARS-BFGL-NGS-85980 (ATF3) } \\
\text { BTB-01766447 (RPL23A) }\end{array}$ & Milk FP, PP & $\begin{array}{l}\text { U.S. Holstein cows ( } 1654 \text { cows, Thirty one dairy traits, including } \\
13 \text { production, health and reproduction traits and } 18 \text { body } \\
\text { conformation traits) were selected for this study }\end{array}$ & U.S & [14] \\
\hline $\begin{array}{l}\text { ARS-BFGL-NGS-24998 (SAA1) } \\
\text { ARS-BFGL-NGS-70836 (SAA1) } \\
\text { ARS-BFGL-NGS-100459 (RPL23A) } \\
\text { ARS-BFGL-NGS-24998 (M-SAA3.2) } \\
\text { Hapmap49309-BTA-78604 (P4HA2) } \\
\text { ARS-BFGL-NGS-70836 (ATF3) }\end{array}$ & Milk PP & $\begin{array}{l}\text { U.S. Holstein cows ( } 1654 \text { cows, Thirty one dairy traits, including } \\
13 \text { production, health and reproduction traits and } 18 \text { body } \\
\text { conformation traits) were selected for this study }\end{array}$ & U.S & [14] \\
\hline ARS-BFGL-NGS-14781 (DDIT3) & Milk FP & U.S. Holstein cows & U.S & [14] \\
\hline rs41569048 (PTHLH) & Milk PP & Dutch Holstein & Netherlands & [18] \\
\hline rs41590827 (PTHLH) & Milk PP & $\begin{array}{l}\text { Dutch Holstein, } 1912 \text { first-lactation Holstein-Friesian cows from } \\
398 \text { commercial herds, records of milk protein, } \\
\text { Significance threshold used for association }\end{array}$ & Netherlands & [18] \\
\hline rs41640170 (HEATR7B2) & Milk PP & Dutch Holstein & Netherlands & [18] \\
\hline Hapmap51303-BTA-74377 (PTHLH) & Milk FP & $\begin{array}{l}\text { Chinese Holsteins } \\
2093 \text { daughters as well as their } 14 \text { corresponding sires were } \\
\text { selected to perform the current study. } \\
\text { The numbers of daughters of the } 14 \text { sires range from } 83 \text { to } \\
358 \text { daughters with an average of } 150 \text {. } \\
\text { Transmission-disequilibrium test (TDT)-based single locus } \\
\text { regression analyses and mixed model-based single locus regression } \\
\text { analyses were performed for association analysis } \\
\text { Milk production traits such as milk yield (MY), milk fat yield (FY), } \\
\text { milk protein yield (PY), milk fat percentage (FP) and milk protein } \\
\text { percentage (PP) were considered for this study }\end{array}$ & China & [32] \\
\hline ARS-BFGL-BAC-2469 (HEATR7B2) & Milk FP, PP & Chinese Holsteins & China & [32] \\
\hline BFGL-NGS-119420 (TRIB3) & Milk FP, PP & $\begin{array}{l}\text { Canadian Holstein } \\
\text { Data from } 462 \text { Canadian Holstein bulls were collected } \\
\text { Single locus LD regression model was used to perform } \\
\text { association analysis }\end{array}$ & Canada & [33] \\
\hline rs29016156 (VEGFA) & Milk PP & Canadian Holstein & Canada & [33] \\
\hline rs41640789 (VEGFA) & Milk FP & Canadian Holstein & Canada & [33] \\
\hline rs41590827 (PTHLH) & Milk PP & Canadian Holstein & Canada & [33] \\
\hline $\begin{array}{l}\text { BTB-00213370 (NUB1) } \\
\text { ARS-BFGL-NGS-71395 (SLC24A2) } \\
\text { BTB-01052867 (SLC24A2) }\end{array}$ & $\begin{array}{l}\text { Milk production } \\
\text { traits }\end{array}$ & $\begin{array}{l}\text { Gir cross Holstein (Girolando) } \\
\text { Records of 305-day milk yield of } 337 \text { dairy cows } \\
\text { a single-marker linear regression model was used for association }\end{array}$ & Brazil & [34] \\
\hline $\begin{array}{l}\text { BovineHD2900015534 (SLC22A8) } \\
\text { BovineHD1200012381 (KLHL1) } \\
\text { BovineHD1200012381 (KLHL1) } \\
\text { BTB-00074258 (TBC1D5) }\end{array}$ & $\begin{array}{l}\text { Milk fatty acids } \\
\text { lactation persistence }\end{array}$ & $\begin{array}{l}445 \text { Chinese Holsteins } \\
15 \text { milk production traits were used for this study } \\
\text { Fixed-effect linear regression model and a mixed-effect linear } \\
\text { model were used for association }\end{array}$ & China & [35] \\
\hline $\begin{array}{l}\text { BovineHD2500005573 (EEF2K) } \\
\text { BovineHD2500005573 (EEF2K) }\end{array}$ & MY & Chinese Holsteins & China & {$[35]$} \\
\hline $\begin{array}{l}\text { rs109421300 (DGAT1) } \\
\text { rs109528658 (EP400) } \\
\text { rs42295213 (EPHA6) } \\
\text { rs134480235 (SLCO1A2) }\end{array}$ & $\begin{array}{l}\text { PP } \\
\text { FY } \\
\text { FP } \\
\text { PY }\end{array}$ & $\begin{array}{l}\text { Chinese Holsteins } \\
452,920 \text { test-day records estimated breeding values from } \\
61,600 \text { cows } \\
\text { SNP regression was performed for association annalysis }\end{array}$ & China & {$[36]$} \\
\hline rs211223469 (DGAT1) & FY, MY & $\begin{array}{l}\text { Korean Holstein } \\
2780 \text { Korean Holsteins ( } 926 \text { bulls and } 1854 \text { cows) were used in the } \\
\text { current study } \\
\text { Single marker regression model for association analysis while MY, } \\
\text { FY, PY, and SCS traits were used as milk production } \\
\text { phenotypic traits }\end{array}$ & Korea & [37] \\
\hline
\end{tabular}


Table 1. Cont.

\begin{tabular}{|c|c|c|c|c|}
\hline SNP (Gene) & Production Traits & $\begin{array}{l}\text { Breed and Phenotypic Traits and Method Used for } \\
\text { Association }\end{array}$ & Country & Author \\
\hline $\begin{array}{l}\text { rs41596885 (PDE4B), } \\
\text { rs42314807 (PDE4B) }\end{array}$ & FY, MY & Korean Holstein & Korea & [37] \\
\hline rs43454033 (ANO2) & FY, MY & Korean Holstein & Korea & [37] \\
\hline $\begin{array}{l}\text { ACACA rs110562092 } \\
\text { ADRB2 rs132839139 } \\
\text { AGPAT6 rs110445169 } \\
\text { CARD15 rs43710288 } \\
\text { CSN1S1 rs43703010 } \\
\text { CSN2 rs43703011 } \\
\text { CSN3 rs } 43703015 \\
\text { FABP4 rs110757796 } \\
\text { FGF2 rs110937773 } \\
\text { GHR rs109136815 } \\
\text { LEP rs11055965 } \\
\text { LEP rs29004170 } \\
\text { LEPR rs43349286 } \\
\text { LPIN1 rs136905033 } \\
\text { LPIN1 rs137457402 } \\
\text { ORL1 rs135588030 } \\
\text { PPARGC1A rs44857081 } \\
\text { PRL rs110684599 } \\
\text { PRL rs211032652 } \\
\text { SCD1 rs41255693 } \\
\text { STAT1 rs } 43705173 \\
\text { STAT1 rs43706906 } \\
\text { STAT5A rs109578101 } \\
\text { STAT5A rs137182814 } \\
\text { TLR2 rs43706433 } \\
\text { XDH rs42890834 }\end{array}$ & MFAs & $\begin{array}{l}1158 \text { Italian Brown Swiss cows and } \\
\text { The bayesian linear animal mode was used for } \\
\text { association study were considered for current study }\end{array}$ & Italy & {$[38]$} \\
\hline
\end{tabular}

MIR2308, LOC104973955, CYHR1, ZNF34, FOXH1,

COMMD5,TONSL, PPP1R16A, MFSD3, LRRC24,

RPL8, C14H8orf33, KIFC2, RECQL4, ZNF7,

ARHGAP39, GPT, LRRC14,

C14H8orf82,LOC100141215, MIR2309, MIR1839,

LOC101907640,LOC101908059, GRINA,

LOC104968841, LOC104973958,LOC104973959,

LOC104973960, ARC, SPATC1, LOC786966,

LOC104973961, OPLAH, HGH1, LOC509114, JRK,

PARP10, MAF1, SHARPIN, CYC1, GPAA1, MROH1,

Milk yield traits

In current study the data were records of 21,068 lactations on primiparous (9910) and multiparous $(11,158)$ Holstein cows
Belgium, The

Netherlands,

Great Britain

and Denmark

LOC100848939, LOC101904969, LOC101905222,

LYPD2, LOC104973965, LYNX1, LOC104973966,

THEM6, SLURP1, LOC78762

SEMA5B, AGPAT3,DGAT1, BTN1A1

SREBF1,FASN,GHR,PRLR, LIPI, LIPK, ECHS1,

ORBS1, NFKB2, CHUK,SCD1, AGPAT6

SLC37A1, MGST1, ABCG2, CSN1S1, CSN2,

CSN1S2, CSN3, PAEP, DGAT1, AGPAT6, ALPL, ANKH, PICALM

SLC15A2, PEPT2, SND1, LEP, CLOCK, CASR, LRRC4, DOCK1, STAT1,STAT3, ELF5

Milk fat traits

Milk fat

rs443751026-GPATCH4 upstream

rs210886822 MGST1 intron

rs209288972 MGST1 upstream

rs208317364 DGAT1 intron

rs133931291 HSF1 intron

LGALS12 upstream

rs383292923 ANK1 intron

rs208624037 GPAT4 intron

rs467849681 ARHGEF28 intron
784 Chinese and 371 Danish Holstein

Milk fatty acids and 16 milk FA traits were selected for current study SNP linear regression models were used for

China association analysis

Montbéliarde, Normande, Holstein

848,068 test-day milk samples from 156,660 cows in the

first three lactations were collected

France

Genotyped in 080 cows (2967 MON, 2737 NOR, and 2306 HOL)

1256 Holstein, 624 Gir, and 477 Girolando cattle

Genomic BLUP Model was used for

association analysis

The database utilized in this study was consisted of 166,628 lactations from 94,124 cows, edited for age at calving (547 to $9095 \mathrm{~d}$ ), calving season (dry or rainy) breed composition (determined by the proportion of

Holstein breed, $1 / 4,3 / 8,1 / 2,5 / 8,3 / 4$, or $7 / 8)$, and contemporary group (determined by herd-year of calving).

Montbéliarde, Normande, Holstein

15 traits (5 linked with milk production, 2 with udder health, and 8 with udder morphology) in Montbéliard (MON), Normande (NOR), and Holstein (HOL) cattle were selected

The phenotypic data was collected from $2515 \mathrm{MON}$,

2203 NOR, and 6321 HOL bulls and verified in

23,926 MON, 9400 NOR, and 51,977 HOL cows

Illumina Bovine SNP50 BeadChip (50K; Illumina Inc., San Diego, CA, USA) was used for genotyping 
Table 1. Cont.

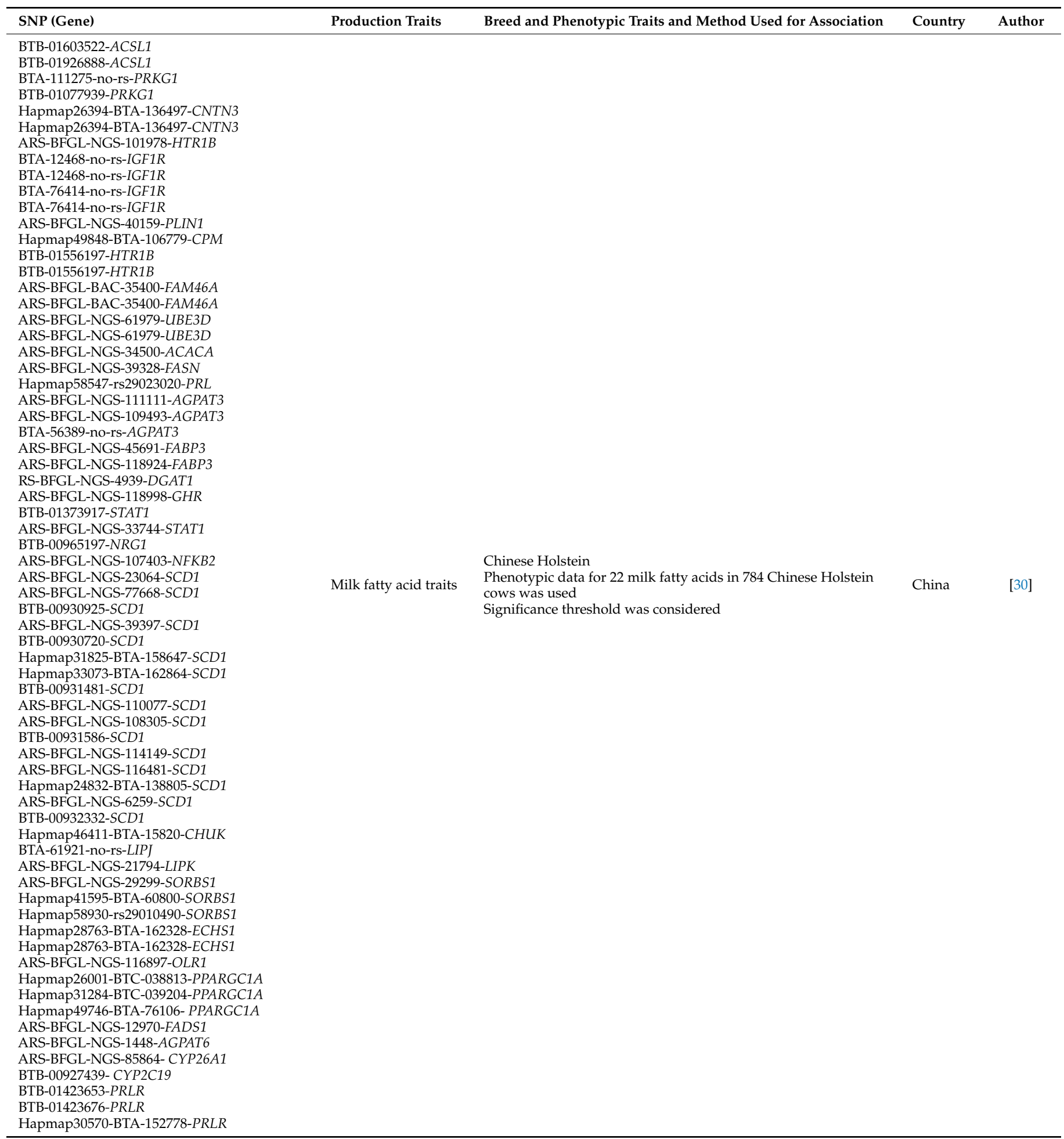

MY: milk yield; FY: fat yield; FP: fat percentage; PY: protein yield; PP: protein percentage; MFAs: Milk fatty acids. Eukaryotic elongation factor 2 kinase (EEF2K); kelch like family member 1 (KLHL1); EPH receptor A6 (EPHA6); solute carrier organic anion transporter family member $1 A 2$ (SLCO1A2); diacylglycerol O-acyltransferase 1(DGAT1); E1A binding protein p400 (EP400); phosphodiesterase 4B (PDE4B), and anoctamin 2 (ANO2).

\section{Transcriptomic Analysis for Screening of Genetic Markers Associated with Milk Production}

RNA-sequencing has been a newly merged tool for screening genetic markers associated with milk production [2,10]. Besides genetic data, the gene expression profile also plays a vital role in exploring the underlying mechanism for complex traits such as milk 
production in dairy cattle. Constantly, Cui et al. performed the transcriptomic profiling of the bovine mammary gland of four lactating Chinese Holstein cows with high and low phenotypic milk protein and fat percentage values. They reported some promising candidate genes (TRIB3, SAA1, M-SAA3.2, SAA3, VEGFA, PTHLH, HSPD1, KRT24, and $R P L 23 A$ ) that were significantly correlated with milk protein and milk fat percentage [10]. Bagnato et al. also reported the significant association of HSPD1 and KRT24 genes with milk yield and protein percentage in Brown Swiss dairy cattle [41]. Furthermore, Khan et al. by using RNA-seq analysis reported the number of genes (DGAT2, ALOX5, AGPAT4, GPAT3, GGH, ALDOA, TKT, SLC11A1 and LAP3) in response to folic acid treatment that were associated with milk protein, milk yield and milk fat in dairy cattle [2]. Consistently, Ouattara et al. reported that vitamin B9 and B12 combine supplementation regulated key genes that were associated with milk production traits. Furthermore, the candidate genes (MYOM1, HP , CDK5R1, MEP1B, DLK1, PPP1R3B, GSTA5, HERC6, LOXL4, SAA3, FUT5, PYCR1 and CACNA2D1) they documented were linked to milk protein and milk fat traits [42]. The genes associated with milk production traits screened out through RNA-seq by different studies have been summarized in Table 2 .

Table 2. Genes identified through the RNA-seq method.

\begin{tabular}{|c|c|c|c|c|}
\hline Genes & Production Traits & Breed & Country & Author \\
\hline $\begin{array}{l}\text { LRRC73, GPX3, APOA4, HP, MFSD2, CDC42EP5, SLC13A5, SMCT1, PAQR9, } \\
\text { SFRP2, ISG15, IFIT1, RSAD2, APOA4, MX1, MX2, USP18, LOC100298356, } \\
\text { HERC6, ISG12(B), TLH29, RSAD2, IFIT1, FKBP5, FKBP,RXRG, ITGAD, LYZ2,HBB } \\
\text { APOC2, ACADVL, PPP1R3B, GALE, PKLR, ANGPTL4, CDKN1A, ODC1, LPIN1, } \\
\text { DUSP1, LMNA, APOA1, ABCG8, Kb, SAA1, PC, SDS, GADD45B, IGF-1R, } \\
\text { CYP7A1,GK, SGLT1, FBP2 }\end{array}$ & MY, FY, PY, FP & Holstein & China & [43] \\
\hline $\begin{array}{l}\text { C4BPA, SLC25A38,BMX, EIF4G3, ZC3H14, FCAMR, DNER, SAA3, HEATR7B2, } \\
\text { TRIB3, SESN2, CHAC1, NR4A1, SAA1, ATF3, RPL23A, CDH16, VEGFA, } \\
\text { BoLA-DQB, ARID1B, PTHLH, H4, FAM71A, THBS4, DDIT3, M-SAA3.2, } \\
\text { HIST1H2AC, P4HA2, HSPD1, KRT24, CDKN1A }\end{array}$ & FP, PP & Holstein & China & [10] \\
\hline GGT5, CYP2J2, ALOX12, MIF, LPL, CPT1A & MFAs & Holstein & China & [44] \\
\hline $\begin{array}{l}\text { CSN2, CSN1S1, LGB, CSN3, CSN1S2, LALBA, GLYCAM1, COX1, FASN, CLU, } \\
\text { COX3, MT-CYB, XDH, MFGE8, EEF1A1, GPAM, ATP6, MT-ND3, ND1, MT-ND4, } \\
\text { NADH, SPP1, SERPINA1, CNTFR, ERBB2, NEDD4L, ANG, GALE, HSPA8, LPAR6, } \\
\text { WAP, NARS, MARS, GARS, CDO1,GATM, INSR, IGF1R, IGFBP3, CRIM1, IGFBP3 }\end{array}$ & Milk protein traits & Holstein & China & [45] \\
\hline $\begin{array}{l}\text { SLC22A1, MAPK9, PPARGC1A, FOXO1, SOCS1, SOCS2, CREB1, HNF4A, HNF4G, } \\
\text { GADD45A, DUSP1, PDGF, SYBU, DDIT4, BAMBI, MTHFR, SLC27A2, PCK1, } \\
\text { CPT2, SIRT3, CYP4A11, PLCB2 }\end{array}$ & Milk protein and fat & Holstein & China & [46] \\
\hline $\begin{array}{l}\text { SLC27A6, ACADM, ACADs, IDH1, FABP4, CACYBP, KLHL9, UBE2B, } \\
\text { RPS, SLC7A8 }\end{array}$ & Milk protein & Holstein & China & [47] \\
\hline $\begin{array}{l}\text { LALBA, LGB, CSN1S1, CSN1S2, CSN2, CSN3, GK,GPD1, DHCR24, COQ2, } \\
\text { AGPAT6, GPAM, LPIN1, BTN1A1, XDH, PLIN2, SCD5,DGAT1, FADS1, FABP3, } \\
\text { SLC22A16, ACSS1, ACSS2, ADIPOQ, HADHB, SLC1A2, SLC1A5, SLC7A4, } \\
\text { SLC7A8, SLC38A3, SARS, PAH, ASNS, RPL,ELOVL, EIF4EBP1, INSIG1 }\end{array}$ & Milk protein and fat & Holstein & China & [47] \\
\hline $\begin{array}{l}\text { LAP3, ASS1, CYP2J2, ATP6AP1, SDS, DGAT2, AGPAT4, GPAT3, ALOX5, } \\
\text { HSD17B12, HACD4, PPT2, ELOVL6, EPHX1, LPL, GUK1, XDH }\end{array}$ & Milk fat and protein yield & Holstein & China & [2] \\
\hline $\begin{array}{l}\text { GPC5,TECTB,IARS2,GUK1,HS3ST5, STMN4,CALB1,LALBA,GLYCAM1 GP2, LPL, } \\
\text { SLC34A2, TUBA1C, CSN1S1, CSN2, PTHLH, BDA20, BDA20, ALOX15, STATH, } \\
\text { BOLA-DQA1, TTC36, PAEP, SPINK4, BTN1A1, TMOD4, SCD, MYBPC1, } \\
\text { ASB11, SLC38A3 }\end{array}$ & MY & Holstein & China & [48] \\
\hline $\begin{array}{l}\text { IRF6, AGPAT6, STAT5A, XDH, B4GALT1,BCL2L11, PRLR, ALOX5, PRKAA1, } \\
\text { NCF1, AGPAT6,STAT5A, CRYL1, GPAM, ALOX12, PGHS-2, CPT1B, SLC27A1, } \\
\text { PRKAR2B, FADS6, PPARD, ACACA, PTGES, EHHADH }\end{array}$ & Milk fat synthesis & Holstein & China & [49] \\
\hline
\end{tabular}

MY: milk yield; FY: fat yield; FP: fat percentage; PY: protein yield; PP: protein percentage; MFAs: Milk fatty acids.

5. Whole-Genome Sequencing for Screening of Genetic Marker Associated with Milk Production in Cattle

Whole-genome sequencing is one of the next-generation sequencing methods utilized to identify a large number of SNPs more quickly and inexpensively [50]. The DNA-seq 
method has been widely excised in livestock genomics to identify the genetic markers associated with milk production traits [51,52]. To perform whole-genome sequencing, the data composed of about $254 \mathrm{k}$ milk, fat, and protein test-day records were collected from 7522 Holstein cows calved from 2006-2016 on two dairy farms in the state of Florida [53]. They reported several genes (CDKN1B, DUSP16, HSF1, EEF1D, VPS28, TONSL, PEX16, MAPK8IP1, CREB3L1 and CRY2) on BTA5, BTA14 and BTA15 that were significantly associated with milk production in traits in dairy cattle. Interestingly, the reported genes in this study are involved in the inositol phosphate mediated signaling pathway, insulin receptor signaling pathway, JNK cascade, stress-activated MAPK cascade, and glutamine metabolic process. These pathways play a major role in maintaining milk production even under stressful condition to regulate the antioxidant system [53]. Similarly, Nanaei et al. performed DNA sequencing for screening genetic makers associated with milk production traits by using the Illumina whole genomes of 21 cattle individuals, including 3 indigenous African breeds (Ankole $n=4$, Kenana $n=4$ and N'Daman =6), and two commercial breeds (Polish Holstein-Friesian $n=3$ and Hereford $n=4$ ). Importantly, they documented some key genes (IGFBP2, B4GALT1, RORA, LPIN1, ATP2B, CSN3, NME1, ACACA, PDE3A, $X P$-CLR, KCNIP4, GHR, NF2, ABCC9, CD44, MACF1, IL15) involved in the regulation of biological function processes such as phosphorus metabolic process, phosphate-containing compound, metabolic process, phosphorylation, protein phosphorylation" and metal ion transport that were significantly related with milk production traits [54]. Recently a study selected 45 blood samples from two-year-old animals and DNA-sequencing was carried to identify genetic markers associated with milk production traits [55]. Interestingly they found nine genes (ADCY5, CACNA1A, CREB1, INHBA, INHBB, PIK3R1, PLCB1, PRKCE, and $S M A D 2$ ) distributed in the ionotropic glutamate receptor pathway, the endothelin signaling pathway, and the gonadotropin-releasing hormone receptor pathway, which are involved in the hormonal regulation of lactation [55]. Whole-genome sequencing for data obtained from 4280 progeny tested Nordic Red Cattle bulls was performed to identify the genetic markers for milk production [56]. In addition, the genes related to milk production traits including DGAT1, HSF1, TRIM26, CLEC16A, NEURL1 (Fat yield), MKL1, CPSF1, ADCK5, LAX1, GHR (milk yield), DGAT1, HSF1, UNKL, PAM16, GLIS2 (protein yield) were documented in Nordic Red Cattle [56].

\section{DNA Polymorphisms and Their Association with Milk Production Traits in Dairy Cattle}

The correlation of DNA polymorphisms with milk production in dairy cattle has been studied for several genes, including SCD, prolactin, DGAT1, leptin, GHR, CSN1S1, ABCG2, $G H$ etc. In Table 3, we have summarized all the major DNA polymorphisms in genes and their association with milk production traits in dairy cattle.

Stearoyl-CoA desaturase 1 (SCD1) located on chromosome 26 has been widely studied for its association with milk production traits in dairy cattle [57-62]. Taniguchi et al. studied the polymorphisms of SCD in Holstein-Friesian, Jersey, Brown Swiss, and Japanese black cattle breeds and found their association with milk fat composition [60]. Similarly, Kgwatala et al. documented the SNP at 3-UTR of SCD and their link with milk fatty acids in Canadian Holstein and Jersey breeds [62]. Consequently, Macciotta et al. reported that the Italian Holsteins with VV genotypes produced more milk and protein than those with AA genotypes. In contrast it has been reported that cows with AA genotypes were producing more milk fat [61]. Furthermore, they highlighted that because of the involvement of $S C D$ gene in energetic pathways, it might be the reason for their association with milk production traits such as milk, yield, and protein [62]. Mele et al. [59] studied the genotypic effect of $S C D$ on milk fatty acids in 297 Italian Holstein Friesian cows. The genotypes in SCD were confirmed through the single-strand conformation polymorphism method. Interestingly, they found that cows having AA genotypes producing more milk fat compared to VV genotypes cows [60]. The above results were also verified by a recent study who found that heterozygous genotypes Chinese Holsteins were producing more milk than the cows of homozygous genotypes [63]. Similarly, Kesek-Wozniak et al. reported that heterozygous 
genotypes Polish Holstein-Friesian cows produced more milk fatty acids in milk compared to VV and AA genotypes cows [64].

Alim et al. [63] reported several SNPs in the SCD gene and their association with milk production traits in Chinese Holsteins. They documented that polymorphism g.10329C/T at exon 5 changed the amino acid alanine to valine. In addition, it was noticed that the two SNPs (g.6926A/G and g.8646A/G) at intron 3 and three polymorphisms (g.10153A/G, g.10213T/C and g.10329C/T) at exon 5 in $S C D$ were significantly associated with milk fat, milk yield, protein yield and protein (\%) in Chinese Holsteins [63]. Recently, it has been documented that $\mathrm{A} 293 \mathrm{~V}$ (c.878C/T) mutation in SCD changed the amino acid alanine to valine and is associated with milk fatty acid in Polish Holstein-Friesian cows [64]. Constantly, Bouwman et al. reported that the A allele of SNP in SCD was associated with higher milk fatty acids [17], while other studies found the less effect of $V$ allele on milk fats in White Fulani and Borgou cattle breeds $[65,66]$.

The polymorphism (DGAT1 K232A) in DGAT1 has been widely studied for its association with milk production traits particularly milk fatty acids in dairy cattle (Table 2) $[64,66,67]$. In addition, it has been documented that $\mathrm{K}$ allele is linked to high milk fat yield, fat content, and protein content and lower milk production protein and lactose yield $[68,69]$. While other studies reported that cows with AA genotypes have higher milk yield and lactose yield and low milk fat and protein contents [70-72]. Based on the above findings, it can be concluded that the DGAT1 K232A can be a target as a useful genetic marker for milk production improvement in dairy cattle.

Raschia et al. conducted a study in Argentina and reported several SNPs in selected candidate genes for their association with production traits in 20 Holstein and 5 Jersey cows. Furthermore they documented that the genes including ARL4A (rs43375517), SCD1 (rs41255693), GH (rs109191047; rs137651874), leptin (rs29004488), OPN (rs132812135), PRLR (rs135164815) and LTF (rs43706485) were associated with milk production traits [73]. Moreover, the SNPs (SNP1; G43737229T, SNP2; G43737229T, SNP3; G43761121A, SNP4; G43761121A, SNP5; G43761121A, SNP6) in breast cancer 1 (BRCA1) gene were significantly associated with milk yield in Karan Fries (Bos taurus $\times$ Bos indicus) cows [74]. However the stage of lactation (lactation 1, 2 and 3) and genotypes (GG, TT, TG) of cows were the key factors that affected the effect of SNPs on milk yield in Karan Fries cows [74].

Fatty acid desaturase 2 (FADS2) is another promising candidate gene that influences milk fatty acid traits and is located on bovine chromosome 29 , with 16 exons encoding 359 amino acid chains [75]. The polymorphism in the FADS2 gene has been widely studied for its association with milk fatty acids (MFAs) in dairy cattle [43,76,77]. Based on published data, it can be recommended that the FADS2 can be a useful candidate marker for milk fat traits improvement in dairy cattle. The detail of FADS2 gene and their polymorphisms has been given in Table 3 .

Ahmed et al. documented few milk protein genes (CSN1S1, CSN2, CSN1S2, CSN3, $\angle A L B A$, and $L G B$ ) that were linked to increase milk protein traits in Sudanese Butana cattle [78]. Consistently, CSN1S1, CSN2CSN2, CSN2, CSN1S2, LALBA genes have been studied for their association with milk production traits in other Bos indicus breeds such as Sarabi, Sistani, Golpayegani and Gir in Iran and Brazil, respectively [79,80]. Moreover, Miluchová et al. proved experimentally that the CSN3 gene was significantly associated with milk production traits in the Slovakian Holstein population [81].

Haruna et al. had documented that the myostatin gene was significantly associated with increasing the amount of milk unsaturated fatty acid and decreasing the amount of saturated fatty acid in New Zealand Holstein-Friesian cross Jersey-Cross Cows. Moreover, they reported that cows with $\mathrm{AD}$ genotypes were linked to decreased saturated fatty acid while cows with AA genotypes correlated with increased milk unsaturated fatty acid [82]. Consequently, it has been documented that fatty acid-binding proteins (FABPS) is significantly associated with milk fatty acids synthesis in Holstein-Friesian $\times$ Jersey $(\mathrm{HF} \times \mathrm{J})$ dairy cows [83]. 
The glycosylphosphatidylinositol-anchored high-density lipoprotein-binding protein1 (GPIHBP1) is a key gene that has been studied for its association with milk fat (\%) and milk protein yield [32,84]. Consistently, another study had reported that GPIHBP1 was significantly correlated with milk fat traits in Chinese Holsteins [85]. They demonstrated that when the expression of GPIHBP1 was decreased, which decreased the LPL binding ability to GPIHBP1 and alternatively, the process of lipolysis was inhibited in mammary epithelial cells, resulting in increased fat in milk [85]. Moreover, Dong et al. [86] illustrated that the decrease of the expression of GPIHBP1, result in an increase in milk protein genes (CSN1S1, CSN1S2, CSN2, and CSN3, lactoferrin) which were associated with the regulation of milk protein biosynthesis [86].

Long-chain acyl-CoA synthetase 1 (ACSL1) is located on chromosome 27 of cattle (Bos Taurus), having 20 exons, 19 introns with 64,883 bp length [87]. The SNPs detected in the ACSL1 gene were genotyped in 992 Chinese Holstein cows and documented the significant association of these SNPs with milk production traits [87]. Consistently a study also documented the up-regulation of sic genes (ACACA, GPAM, ACSL1, FASN, LPIN1 and ACSL6) in dairy cattle during lactation [88]. Twenty candidate genes associated with milk fatty acid traits in Chinese Holstein cows were identified in a previous study, and ACSL1 was one of them [30]. Furthermore, a study had documented that mutation in the ACSL1 gene plays a key role in the milk fat enhancement of Yak [89]. Fan et al. experimentally proved that the expression (increase and decrease) of ASCL4 was significantly associated with milk fat synthesis in bovine mammary epithelial cells [90]. The interaction of ASCL4 was reported with ASCL1, FADS2, FASN, PPARD, CPT1A, FABP3 and ELOVL6 which are key genes associated with milk production traits. Based on the above findings, we can conclude that ASCL1 can be considered a key regulator of milk fat synthesis.

Acylglycerol-3-phosphate O-acyltransferase 3 (AGPAT3), located on Bos taurus autosome 1 (BTA1) having eight exons encoding 376 amino acid chains, is a crucial acyltransferase that is involved in triglyceride (TG) and phospholipid biosynthesis [91]. AGPAT3 has been identified through GWAS studies as a positional candidate gene affecting milk fatty acids in dairy cattle $[30,91,92]$. A study by using GWAS study documented the AGPAT3 and was found to be significantly linked with milk fatty acid traits in Chinese and Danish Holstein populations [39]. Recently, a study detected a SNP1 (g.12264 C > T) at promoter region, SNP2 (g.18852 C > T) in exon 5 and other six SNPs (g.18658 G > A, g.20046 G > A, g.23034 C > A, g.28332 C > T, g.28484 C > T, and g.28731 A > G) on intronic regions of AGPAT3 in dairy cattle [93]. All the SNPs reported by Sun et al. showed significant association with at least one phenotypic trait of milk production. Similarly, Shi et al. reported 17 SNPs in AGPAT3 that were associated with milk fatty acid traits in Chinese Holstein cows [94]. Littlejohn et al. also documented several SNPs of AGPAT3 in Holstein-Friesian $\times$ Jersey crossbreed that were associated with milk fat synthesis [95]. The detail of SNPs in AGPAT3 has been given in Table 3.

Prolactin is another key gene having an important role in lactation initiation and maintenance in mammals [96]. Several polymorphisms within prolactin have been identified which were significantly associated with milk production traits in dairy cattle [96,97]. Poglo et al. identified $B A C H 2, E 2 F 3$ and $K D M 5 A$ as key genes that are involved in the regulation of milk fat synthesis in the mammary gland of dairy cattle [98]. 
Table 3. The variations in genes and their association with milk production traits in dairy cattle.

\begin{tabular}{|c|c|c|c|c|c|c|}
\hline Gene (Location) & Polymorphism (Location) & $\begin{array}{l}\text { Change in Amino } \\
\text { Acid Sequence }\end{array}$ & Production Trait & Breed & Country & Author \\
\hline SERPINA1 (BTA21) & $\begin{array}{l}\text { rs208607693 (5- flanking region) } \\
\text { rs210222822 (Exon-2) }\end{array}$ & & MY, FY, PY, PP & Chinese Holstein & China & [99] \\
\hline SERPINA1 (BTA21) & $\begin{array}{l}\text { rs41257068 (Exon-2) } \\
\text { rs207601878 (Intron-3) }\end{array}$ & & MY, FY, PY, PP, FP & Chinese Holstein & China & [99] \\
\hline$S C D$ (BTA21) & c.878C/T (Exon5) & p.A293V & MFAs & $\begin{array}{l}\text { Holstein Friesian } \times \text { Jersey } \\
\text { dairy cows }\end{array}$ & Newzealand & {$[100]$} \\
\hline SCD (BTA21) & c.1783A/G (3-UTR) & & MF & $\begin{array}{l}\text { Holstein Friesian } \times \text { Jersey } \\
\text { dairy cows }\end{array}$ & Newzealand & [100] \\
\hline \multirow{3}{*}{$S C D$} & g. $10329 \mathrm{C}>\mathrm{T}$ & Alanine to valine & \multirow{3}{*}{ MY, FY, PY, PP } & \multirow{3}{*}{ Chinese Holstein } & \multirow{3}{*}{ China } & \multirow{3}{*}{ [101] } \\
\hline & g. $10153 \mathrm{G}>\mathrm{A}$ & & & & & \\
\hline & g.10213T > C & & & & & \\
\hline$S C D$ & g. $10329 \mathrm{C}>\mathrm{T}$ & Alanine to valine & MFA & Canadian Jersey cows & Canada & {$[62]$} \\
\hline$S C D$ & g. $10329 \mathrm{C}>\mathrm{T}$ & Alanine to valine & FY, PY, MY & Holstein cows & Belgium & [102] \\
\hline$S C D$ & A293V SNP & & MFAs & $\begin{array}{l}\text { Polish } \\
\text { Holstein-Friesian }\end{array}$ & Poland & {$[64]$} \\
\hline$S C D$ & A293V SNP & & MFAs & Italian Holsteins & Italy & [59] \\
\hline CD4 (BTA5) & g. $13598 \mathrm{C}>\mathrm{T}$ & & MY, FY, PY & Chinese Holstein & China & [103] \\
\hline STAT5B (BTA19) & g.31562T > C; Exon 16 & & MY, PY & Chinese Holstein & China & [103] \\
\hline \multirow[t]{2}{*}{ DDIT3 (BTA5) } & $\begin{array}{l}\text { g.56283814C > T;5-flanking region } \\
\text { g.56284880C > T;5-flanking region }\end{array}$ & & FP, FY, PP & Chinese Holstein & China & [15] \\
\hline & c. $* 21 \mathrm{~A}>\mathrm{G}(5-\mathrm{UTR})$ & & MY, FY, PY & & China & [15] \\
\hline RPL23A (BTA19) & $\begin{array}{l}\text { g.20702088A > G 5-flanking region } \\
\text { g.20702122C > G 5-flanking region } \\
\text { g.20702782_83insG 5-flanking region }\end{array}$ & & MY, FY, PY & Chinese Holstein & China & [15] \\
\hline SESN2 (BTA19) & $\begin{array}{l}\text { g.125716884A > G, 5-flanking region } \\
\text { g.125714860_125714872del, } \\
\text { 5-flanking region } \\
\text { g.125714806delinsCCCC, } \\
\text { 5-flanking region } \\
\text { g.125714850A > G, 5-flanking region } \\
\text { g.125716686A > G, } \\
\text { 5-flanking region }\end{array}$ & & MY, FY, PY & Chinese Holstein & China & [15] \\
\hline NR4A1 (BTA5) & $\begin{array}{l}\text { g.27994068A > G, 5-flanking region } \\
\text { g.27993737A > G, 5-flanking region } \\
\text { g.27992897C > T, 5-flanking region } \\
\text { c. }{ }^{*} 138 \mathrm{~A}>\mathrm{G}(5 \text {-UTR) }\end{array}$ & & MY, FY and PY & Chinese Holstein & China & [15] \\
\hline \multirow[t]{5}{*}{ PTK2 (BTA14) } & g.4061098T > G (Exon5) & p.Ile981Met & MY, PY and FP & Chinese Holstein & China & [104] \\
\hline & g. 3895208T > G (Intron2) & & MY, PY and FP & & & \\
\hline & g. $4059863 \mathrm{~A}>\mathrm{C}$ (Intron13) & & MY, FY, PY and FP & & & \\
\hline & g.3968605A > G (Intron6) & & MY, PY and FP & & & \\
\hline & g.7012367T > C (Intron16) & & MY, FP and PP & & & \\
\hline UGDH (BTA6) & $\begin{array}{l}\text { rs61000233G/A } \\
\text { (Exon1) } \\
\text { rs60966191A/T } \\
\text { (Exon12) }\end{array}$ & & MY & Chinese Holstein & China & [105] \\
\hline \multirow[t]{4}{*}{ SAA1 (BTA11) } & $\begin{array}{l}\text { g.-1788C > T (Promoter) } \\
\text { g.-963C > A (Promoter) } \\
\text { g.-781 A > G (Promoter) }\end{array}$ & & PY, MY & Chinese Holstein & China & [106] \\
\hline & c. $+2510 \mathrm{~A}>\mathrm{G}(\mathrm{EXON} 3)$ & Gly48Asp & MY, FP and PY & & & \\
\hline & c. $+2535 \mathrm{C}>\mathrm{T}(\mathrm{EXON} 3)$ & R56R & PY, MY & & & \\
\hline & c. $+2565 \mathrm{G}>\mathrm{A}(\mathrm{EXON} 3)$ & P66P & PY, MY & & & \\
\hline SAA2 (BTA29) & $\begin{array}{l}\text { c. }-22 \mathrm{G}>\mathrm{A} \text { (Promoter) } \\
\text { c. } 17 \mathrm{G}>\mathrm{C} \text { (Promoter) } \\
\text { c. } 114 \mathrm{G}>\text { A (Promoter) }\end{array}$ & & MY, FY and PY & Chinese Holstein & China & [107] \\
\hline ACACB (BTA17) & $\begin{array}{l}\text { g.66218726T > C (Promoter) } \\
\text { g.66218117G > A(Promoter })\end{array}$ & & $\begin{array}{l}\text { milk production } \\
\text { traits }\end{array}$ & Chinese Holstein & China & [108] \\
\hline
\end{tabular}


Table 3. Cont.

\begin{tabular}{|c|c|c|c|c|c|c|}
\hline Gene (Location) & Polymorphism (Location) & $\begin{array}{l}\text { Change in Amino } \\
\text { Acid Sequence }\end{array}$ & Production Trait & Breed & Country & Author \\
\hline ERBB2 (BTA19) & $\begin{array}{l}\text { g.22400A > G (Intron-23) } \\
\text { g.22346A > T (Intron-23) } \\
\text { g.16431C > G (Intron-14) } \\
\text { g.19414A > G (Intron-14) } \\
\text { g.11680C > T (Intron-8) } \\
\text { g.10727A > G (Intron-7) } \\
\text { g.23650T > C (Intron-26) } \\
\text { g.22268T > C (Exon 23) } \\
\text { g.20982del (Intron-19) }\end{array}$ & & Milk PP & Chinese Holstein & China & [109] \\
\hline$E R B B 2$ & $\begin{array}{l}\text { g. } 873 \mathrm{~T}>\mathrm{C} \text { (5-flanking region) } \\
\text { g.21561A > G (Exon-21) }\end{array}$ & & MY, FY, FP, PY, PP & Chinese Holstein & China & [109] \\
\hline HSPA8 (BTA15) & $\begin{array}{l}\text { rs132976221 } \\
\text { g.4218T > G (Intron-3) }\end{array}$ & & MY, PY, FY & Chinese Holstein & China & [109] \\
\hline HSPA8 & $\begin{array}{l}\text { rs136632043 } \\
\text { g.4218T > G-exon9 }\end{array}$ & & MY, PY, FY & Chinese Holstein & China & [109] \\
\hline ECHS1 (BTA6) & g.25858322C > T-exon 3 & $\begin{array}{l}\text { Leucine } \\
\text {-phenylalanine }\end{array}$ & MFAs & Chinese Holstein & China & [110] \\
\hline ECHS1 & g.25857784C > T(exon 2) & & MFA & Chinese Holstein & China & [110] \\
\hline FADS2 (BTA29) & c. $908 \mathrm{C}>\mathrm{T}($ Exon 7$)$ & 294Ala > Val & MY, PY, FY, FP & Chinese Holstein & China & [111] \\
\hline FADS2 & c.1571 G > A (3-UTR) & & MY & Chinese Holstein & China & [111] \\
\hline FADS2 & c.1571G > A (3-UTR) & & MFA & Chinese Holstein & China & [75] \\
\hline FADS2 & rs209202414 G > A & & MFA & HS and Jersey & $\begin{array}{l}\text { Romania } \\
\text { and } \\
\text { Poland }\end{array}$ & [77] \\
\hline \multirow[t]{3}{*}{ FADS2 } & rs211580559 G > A(exon 7) & $(294 \mathrm{Ala}>\mathrm{Val})$ & MFA & & & {$[76]$} \\
\hline & rs42187261 G > A (exon 8) & & MFA & & & [76] \\
\hline & $\begin{array}{l}\text { rs109772589 G > A (3-UTR) } \\
\text { rs136261927 G > A (3-UTR) } \\
\text { rs109772589 G > A (3-UTR) }\end{array}$ & & MFA & Canadian Holstein & Canada & {$[76]$} \\
\hline THRSP (BTA29) & rs42714482 (exon 7) & Ala51Val & MFA & Jersey and Polish Holstein & Poland & {$[112]$} \\
\hline \multirow[t]{2}{*}{ SCD 1 (BTA26) } & rs41912290 G > A (Exon16) & Leu/Pro & MFA & Holstein & US & [113] \\
\hline & rs41255691 (Exon 5) & & & Holstein & US & [113] \\
\hline SCD5 (BTA6) & $\begin{array}{l}\text { ss252452201 (exon 3) } \\
\text { ss252452202(exon 3) } \\
\text { ss252452203(exon 3) } \\
\text { rs43687655 (exon 4) }\end{array}$ & & MFA & Holstein & US & [113] \\
\hline INSIG1 (BTA4) & $\begin{array}{l}\text { ss252452218 (Exon 1) } \\
\text { ss252452220 (exon4) } \\
\text { ss252452222 (exon5) }\end{array}$ & $\begin{array}{l}\text { Ser/Gly } \\
\text { Leu/Phe }\end{array}$ & MFA & Holstein & US & [113] \\
\hline INSIG2(BTA4) & $\begin{array}{l}\text { ss252452227 (5'UTR) } \\
\text { ss252452228 (5'UTR) } \\
\text { ss252452229 (5'UTR) }\end{array}$ & & MFA & Holstein & US & [113] \\
\hline MBTPS1 (BTA18) & ss252452238 (Exon 1) & & MFA & Holstein & US & [113] \\
\hline MBTPS2 (BTA18) & ss252452240 (5'UTR) & & MFA & Holstein & US & [113] \\
\hline SCAP (BTA12) & $\begin{array}{l}\text { ss252452209 (5'UTR) } \\
\text { ss252452210 (5'UTR) } \\
\text { ss252452212 (exon 3) } \\
\text { ss252452215 (exon 7) } \\
\text { ss252452217 (exon 7) } \\
\text { rs41255691 (exon5) }\end{array}$ & & MFA & Holstein & US & [113] \\
\hline SCAP (BTA12) & ss252452215 (exon 7) & Pro/Ser & MFA & Holstein & US & [113] \\
\hline MAP4K4 (BTA11) & c. $2061 \mathrm{~T}>\mathrm{G}($ exon 18$)$ & & PP, MY & Chinese Holstein & China & [114] \\
\hline IGF2R & g.72479 G > A (exon 24) & & MY, PY, LC & Polish Holstein & Poland & [115] \\
\hline Sirtuins (BTA28) & g.-274C > G (Promoter) & & MY, FY, FP, LL & $\begin{array}{l}\text { Chinese Red Steppe } \\
\text { Agerolese, } \\
\text { Qinchuan } \\
\text { Nanyang, Jiaxian, Luxi }\end{array}$ & Italy & [116] \\
\hline$S C D$ & SCD1-A293V & A293V & MFA & Holstein & Netherlands & [65] \\
\hline FASN (BTA19) & $\begin{array}{l}\text { rs41919999 (Intron 12) } \\
\text { rs41919992 (Exon-27) } \\
\text { rs133498277 (Intron 28) } \\
\text { rs41919984 (Exon 37) } \\
\text { rs41919986 (Exon-42) }\end{array}$ & & MCFAs & Chinese Holstein & China & [117] \\
\hline
\end{tabular}


Table 3. Cont.

\begin{tabular}{|c|c|c|c|c|c|c|}
\hline Gene (Location) & Polymorphism (Location) & $\begin{array}{l}\text { Change in Amino } \\
\text { Acid Sequence }\end{array}$ & Production Trait & Breed & Country & Author \\
\hline FASN & rs41919985 (Exon-39) & $\begin{array}{l}\text { alanine } \\
\text { 2266threonine }\end{array}$ & MCFAs & Chinese Holstein & China & [117] \\
\hline PPARGC1A (BTA6) & rs109579682-Intron-9 & & MCFAs & Chinese Holstein & China & [117] \\
\hline ABCG2 (BTA6) & rs137757790-Intron-7 & & MCFAs & Chinese Holstein & China & [117] \\
\hline IGF1 (BTA5) & rs109763947-5'-UTR & & MCFAs & Chinese Holstein & China & [117] \\
\hline$A B C G 2$ & ABCG2-Y581S & & MY, FP, PP & Iranian Holstein & Iran & [118] \\
\hline LEPR (BTA3) & LEPR-T945M & & MY, FP, PP & Iranian Holstein & Iran & [118] \\
\hline$S C D 1$ & SCD1-A293V & & MY, FP, PP & Iranian Holstein & Iran & [118] \\
\hline DGAT1 (BTA14) & DGAT1 K232A & & MFA & Modicana cows & Italy & [119] \\
\hline PRLR (BTA14) & $\begin{array}{l}\text { g. } 38948871 \mathrm{C}>\mathrm{T}\left(5^{\prime}\right. \\
\text { flanking region) } \\
\text { g.38949011G }>\mathrm{A}\left(5^{\prime}\right. \\
\text { flanking region) } \\
\text { g.39115345 T > C (Exon4) }\end{array}$ & & MFA & & & [120] \\
\hline PRLR & g.39115344G > A (Exon4) & Serine- asparagine & MFA & & & [120] \\
\hline СНUК (BТА26) & $\begin{array}{l}\text { g.21008688G > T ( } 5^{\prime} \\
\text { flanking region) } \\
\left.\text { g.20966385C > G ( } 3^{\prime} \text { UTR }\right) \\
\left.\text { g.20966354C > T( } 3^{\prime} \text { UTR }\right)\end{array}$ & & MFA & Chinese Holstein & China & [120] \\
\hline MOGAT1 (BTA2) & $\begin{array}{l}\text { g.111599360A > G T ( } 5^{\prime} \\
\text { flanking region) } \\
\text { g.111601747 T > A T ( } 5^{\prime} \\
\text { flanking region) }\end{array}$ & & MFA & Chinese Holstein & China & [120] \\
\hline MINPP1 (BTA26) & $\begin{array}{l}\text { g. } 9206582 \mathrm{C}>\mathrm{T}\left(3^{\prime} \text { UTR) }\right. \\
\text { g. } 9207070 \mathrm{~A}>\mathrm{G} \text { (intron 5) }\end{array}$ & & MFA & Chinese Holstein & China & [120] \\
\hline CPM (BTA5) & $\begin{array}{l}\text { g. } 45079507 \mathrm{~A}>\mathrm{G}-5^{\prime} \\
\text { flanking region } \\
\text { rs208252716 } \\
\text { g.45080228C > A-5' } \\
\text { flanking region } \\
\text { rs109638242 } \\
\text { g.45080335C > G-5' } \\
\text { flanking region } \\
\text { rs136799678 } \\
\text { g.45162113G > A 3-UTR } \\
\text { rs134841257 } \\
\text { g.45163633G > T 3- flanking region } \\
\text { rs110822514 } \\
\text { g.45164215A > G-3- flanking region } \\
\text { rs462818932 } \\
\text { g.45164996A }>\text { G-3- flanking region } \\
\text { rs382501675 }\end{array}$ & & MFA & Chinese Holstein & China & [121] \\
\hline$C P M$ & $\begin{array}{l}\text { apmap49848-BTA-106779 } \\
\text { (Intron 2) }\end{array}$ & & MFA & Chinese Holstein & China & [30] \\
\hline LIPK (BTA26) & $\begin{array}{l}\text { g.10428101G > A } \\
\text { rs110322221 (5-UTR) } \\
\text { g.10449831C > A } \\
\text { rs42774527 (Exon 11) } \\
\text { g.10214117A > C } \\
\text { rs41606812 (5' } \\
\text { flanking region) } \\
\text { g.10217380C > A } \\
\text { rs211373799 (5-UTR) } \\
\text { g.10247997T > C } \\
\text { rs42107056 ( } 3^{\prime} \text { UTR) }\end{array}$ & & MFAs & Chinese Holstein & China & [122] \\
\hline LIPJ (BTA26) & $\begin{array}{l}\text { g.10250098C > T (3- flanking } \\
\text { region) } \\
\text { rs42107122 } \\
\text { g.10250120A > G } \\
\text { ss158213049726 (3- flanking } \\
\text { region) } \\
\text { g.10251075G > T } \\
\text { rs209219656 (3- flanking } \\
\text { region) } \\
\text { g.10251111T > C } \\
\text { rs42107114 (3- flanking } \\
\text { region) }\end{array}$ & & MFAs & Chinese Holstein & China & [122] \\
\hline DGAT1 (BTA14) & DGAT1 (K232A) & & MFY & Dutch Holstein & Israel & [123] \\
\hline
\end{tabular}


Table 3. Cont.

\begin{tabular}{|c|c|c|c|c|c|c|}
\hline Gene (Location) & Polymorphism (Location) & $\begin{array}{l}\text { Change in Amino } \\
\text { Acid Sequence }\end{array}$ & Production Trait & Breed & Country & Author \\
\hline DGAT1 & DGAT1 (K232A) & & MPTs & Holstein & USA & [124] \\
\hline DGAT1 & DGAT1 (K232A) & & MPTs & Irish Holstein & Ireland & [125] \\
\hline DGAT1 & rs109663724 & & PY, FY, MY & & USA & [126] \\
\hline DGAT1 & $\begin{array}{l}\text { rs132699547 } \\
\text { rs135423283 } \\
\text { rs135576599 } \\
\text { rs13675432 }\end{array}$ & & PY, FY & Holstein & USA & [126] \\
\hline DGAT1 & DGAT1 (K232A) & & $\begin{array}{l}\text { MPTs + milk } \\
\text { coagulation } \\
\text { properties }\end{array}$ & Italian Holstein & Italy & [127] \\
\hline DGAT1 & DGAT1 (K232A) & & MFY, MPY, MFAs & Holstein & Netherlands & [128] \\
\hline DGAT1 & DGAT1 (K232A) & & MPTs, LC & Holstein & Netherlands & {$[68]$} \\
\hline DGAT1 & DGAT1 (K232A) & & MFAs & $\begin{array}{l}\text { Holstein-Friesian, Jersey, } \\
\text { Frisón } \\
\text { Negro, Montbeliarde, and } \\
\text { Overo } \\
\text { Colorado }\end{array}$ & Chile & [67] \\
\hline DGAT1 & DGAT1 (K232A) & & MPTs & Holstein & Netherlands & [65] \\
\hline DGAT1 & DGAT1 (K232A) & & MPTs & $\begin{array}{l}\text { Borgou and White Fulani } \\
\text { cattle }\end{array}$ & Benin & [66] \\
\hline DGAT1 & DGAT1 (K232A) & & MPTs & Holstein & $\begin{array}{l}\text { Czech } \\
\text { Repub- } \\
\text { lic }\end{array}$ & [129] \\
\hline DGAT1 & DGAT1 (K232A) & & MFAs & Polish Holstein & Poland & [64] \\
\hline DGAT1 & DGAT1 (K232A) & & MPTs & Polish Holstein & Poland & [130] \\
\hline DGAT1 & DGAT1 (K232A) & & $\begin{array}{l}\text { Milk metabolome } \\
\text { and proteome }\end{array}$ & Holstein & Netherlands & [131] \\
\hline DGAT1 & DGAT1 (K232A) & & MFAs & Holstein & Netherlands & [132] \\
\hline DGAT1 & DGAT1 (K232A) & & FY, PY & Holstein & Germany & [133] \\
\hline DGAT1 & DGAT1 (K232A) & & MPTs & Polish Holstein & Poland & [134] \\
\hline DGAT1 & DGAT1 (K232A) & & FP, MFAs & Romanian Holstein & Romania & [135] \\
\hline DGAT1 & DGAT1 (K232A) & & MFAs & Holstein & Netherlands & [69] \\
\hline DGAT1 & DGAT1 (K232A) & & MFAs & Holstein & Netherlands & [136] \\
\hline DGAT1 & DGAT1 (K232A) & & FY, PY, MY & Holstein & Netherlands & [71] \\
\hline DGAT1 & DGAT1 (K232A) & & MFAs & Holstein & Netherlands & [137] \\
\hline DGAT1 & DGAT1 (K232A) & & MPTs & Holstein cross Normande & France & [70] \\
\hline DGAT1 & DGAT1 K232A & & FC, PC & $\begin{array}{l}\text { indigenous Ongole cattle, } \\
\text { Indian Jersey, Holstein }\end{array}$ & India & [138] \\
\hline DGAT1 & $\begin{array}{l}\text { rs109421300 G > A (5'flanking } \\
\text { region) }\end{array}$ & & FP & Holstein & China & [1] \\
\hline JAK2 (BTA8) & rs210148032 C > T(exon 16) & & PP & Holstein & China & [1] \\
\hline JAK2 & JAK2/RsaI (rs110298451) & & PY & $\begin{array}{l}\text { Polish Holstein, } \\
\text { Montbeliarde, } \\
\text { Simmental, Jersey }\end{array}$ & Poland & [139] \\
\hline \multirow[t]{2}{*}{ ELOVL6 (BTA6) } & $\begin{array}{l}\text { g16379651A > G ELOVL6-Intron } 3 \\
\text { g16458976A > G ELOVL6-Intron } 3\end{array}$ & & MY & Holstein & China & [3] \\
\hline & g16511290A > G ELOVL6-3' UTR & & MY, MFC (\%) & Holstein & China & [3] \\
\hline ACSL1 (BTA27) & 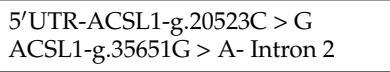 & & PC (\%) & Holstein & China & [140] \\
\hline ACSL1 & $\begin{array}{l}\text { ACSL1-g.35446C > T- Intron } 2 \\
\text { ACSL1-g.35651G > A- Intron } 2 \\
\text { g.51472C > T- ACSL1-Intron } 11\end{array}$ & & $\begin{array}{l}\text { TDMY (kg), FC } \\
(\%), \text { PC }(\%)\end{array}$ & Holstein & China & [140] \\
\hline AGPAT6 (BTA27) & $\begin{array}{l}\text { BovineHD2700010331 } \\
\text { g.36175805C.T (Intron 1) } \\
\text { ARS-BFGL-NGS-57448 } \\
\text { g.36155097C.T (5-UTR exons) }\end{array}$ & & MFY & $\begin{array}{l}\text { New } \\
\text { Zealand Holstein-Friesian } \\
\text { cross Jersey }\end{array}$ & Newzealand & [95] \\
\hline
\end{tabular}


Table 3. Cont.

\begin{tabular}{|c|c|c|c|c|c|c|}
\hline Gene (Location) & Polymorphism (Location) & $\begin{array}{l}\text { Change in Amino } \\
\text { Acid Sequence }\end{array}$ & Production Trait & Breed & Country & Author \\
\hline AGPAT3 (BTA1) & $\begin{array}{l}\text { g. } 146702957 \mathrm{G}>\mathrm{A} \\
\text { rs210638665 (5' flanking region) } \\
\text { g. } 146704373 \mathrm{~A}>\mathrm{G} \\
\text { rs209442459 (5' flanking region) } \\
\text { g. } 146704618 \mathrm{~A}>\mathrm{G} \\
\text { rs110551271 (5' flanking region) } \\
\text { g. } 146704699 \mathrm{G}>\mathrm{A} \\
\text { rs110278717 (5' flanking region) }\end{array}$ & & MFAs & Holstein & China & [94] \\
\hline AGPAT3 & $\begin{array}{l}\text { g.28731 A > G } \\
\text { g.12264 C > T }\end{array}$ & & $\mathrm{PP}(\%), \mathrm{FP}(\%), \mathrm{MY}$ & Holstein & China & [93] \\
\hline ATPase 6 (BTA20) & m.8308A > G (Exon 2) & & MFY & Holstein & China & [141] \\
\hline BoLA (BTA23) & BoLA-DRB3.2 (exon 2) & & Milk microbiota & Holstein & Canada & [142] \\
\hline CSN3 (BTA6) & $\begin{array}{l}\text { g.10993T > A (exon 4) } \\
\text { g.10888T > C (exon 4) } \\
\text { g.10924C > A (exon 4) } \\
\text { g.10985G > A (exon 4) }\end{array}$ & $\begin{array}{l}\text { Iso-Thr } \\
\text { Ala-Asp } \\
\text { Ala-Ala }\end{array}$ & $\mathrm{PP}(\%), \mathrm{FP}(\%)$ & Holstein & China & {$[63]$} \\
\hline CSN3 & g.10944A > G(exon 4) & Serine $>$ Glycine & $\begin{array}{l}\text { MY, FY, FP (\%), } \\
\text { PY }\end{array}$ & Holstein & China & [63] \\
\hline CSN3 & g.12703T > G & & MY, FY, PY, PP(\%) & Holstein & China & {$[63]$} \\
\hline GHR (BBTA20) & GHR-F279Y polymorphism & $\begin{array}{l}\text { phenylalanine to } \\
\text { tyrosine }\end{array}$ & $\begin{array}{l}\text { MY, PC (\%), FC } \\
(\%), \text { LC (\%) }\end{array}$ & Holstein & Germany & {$[143]$} \\
\hline $\begin{array}{l}\text { HSP90AB1 } \\
\text { (BBTA23) }\end{array}$ & SNP g.4338T > C & & MY & Frieswal, Sahiwal & India & [144] \\
\hline HTR1B (BTA9) & $\begin{array}{l}\text { rs207969357 } \\
\text { g.17303383G > T (Exon 1) }\end{array}$ & Alanine to Serine & MFAs & Holstein & China & [145] \\
\hline HTR1B & $\begin{array}{l}\text { rs207969357 } \\
\text { g.17307103A > T (Promoter) } \\
\text { rs476055046 } \\
\text { g.17305206 T > G (Promoter) } \\
\text { rs476055046 } \\
\text { g.17303761C > T (Promoter) } \\
\text { rs208945882 } \\
\text { g.17303042C > G (Exon-1) }\end{array}$ & & MFAs & Holstein & China & [145] \\
\hline IGF2 (BTA29) & $\begin{array}{l}\text { g.8656C > T-Exon } 2 \\
\text { g.24507G > T-Exon } 10\end{array}$ & & FY, PY, PC & Polish Holstein & Poland & [146] \\
\hline IGF2 & $\begin{array}{l}\text { rs42196909 } \\
\text { IGF2.g-3815A > G } \\
\text { rs42196901 }\end{array}$ & & MY, PY & Irish Holstein & Ireland & {$[147]$} \\
\hline IGFBP2 (BTA9) & $\begin{array}{l}\text { rs133488718-Intron } 3 \\
\text { rs133235938- Intron } 5\end{array}$ & & MY & Holstein & UK & [148] \\
\hline PDE9A (BTA2) & $\begin{array}{l}\text { c. }-2012 \mathrm{~T}>\mathrm{C}(\mathrm{rs} 42140305) \\
\text { c. }-2005 \mathrm{~A}>\mathrm{G}(\mathrm{rs} 381951806)\end{array}$ & & MY, PY & Holstein & China & [149] \\
\hline LAP3 (BTA6) & $\begin{array}{l}\text { g.24564G > A (ss196003366) } \\
\text { g.24794T > G } \\
\text { g.24803T }>\text { C } \\
\text { g.24846T }>\text { C } \\
\text { g.25415T }>\text { C }\end{array}$ & & MFP (\%), PP (\%) & Holstein & China & [150] \\
\hline Lipin 1 (BTA11) & $\begin{array}{l}\text { g. } 86129263 C>G \\
\text { rs211527179-5-flanking region }\end{array}$ & & FY, FP (\%), PY & Holstein & China & [151] \\
\hline Lipin 1 & $\begin{array}{l}\text { c. } 637 \mathrm{~T}>\mathrm{C} \\
\text { rs110871255-exon } 5\end{array}$ & Methionine-thr & MY, FP (\%),PY & Holstein & China & [151] \\
\hline Lipin 1 & $\begin{array}{l}\text { c.708A > G } \\
\text { rs110161110-exon } 5\end{array}$ & Thr-Ala & MY, PY & Holstein & China & [151] \\
\hline Lipin 1 & $\begin{array}{l}\text { c. } 1521 C>\text { T } \\
\text { rs207681322-exon } 8\end{array}$ & Proline-Serine & MY, FY, FP (\%), PY & Holstein & China & [151] \\
\hline Lipin 1 & $\begin{array}{l}\text { c. } 1555 \mathrm{~A}>\mathrm{C} \\
\text { rs137642654-exon } 8\end{array}$ & Histidine-Proline & MY, FP (\%),PY & Holstein & China & [151] \\
\hline Lipin 1 & $\begin{array}{l}\text { g. } 86049523 \mathrm{C}>\mathrm{T} \\
\text { rs135886289-3-flanking region } \\
\text { g.86049389C > T } \\
\text { rs109039955-3-flanking region }\end{array}$ & & MY, FY, PY, PP (\%) & Holstein & China & {$[151]$} \\
\hline Leptin (BTA4) & accession number MN119554 SNP & p.Ala80Val & MFAs & $\begin{array}{l}\text { Holstein Friesian } \times \text { Jersey } \\
\text { dairy cows }\end{array}$ & Newzealand & [152] \\
\hline
\end{tabular}


Table 3. Cont.

\begin{tabular}{|c|c|c|c|c|c|c|}
\hline Gene (Location) & Polymorphism (Location) & $\begin{array}{l}\text { Change in Amino } \\
\text { Acid Sequence }\end{array}$ & Production Trait & Breed & Country & Author \\
\hline$M B L(B T A 26)$ & $\begin{array}{l}\text { g. } 2686 \mathrm{~T}>\text { C-Exon } 2 \\
\text { g. } 2651 \mathrm{G}>\text { A-Exon } 2\end{array}$ & & FC (\%), PC (\%) & $\begin{array}{l}\text { Bohai Black Chinese } \\
\text { Holstein } \\
\text { Luxi Yellow }\end{array}$ & China & [153] \\
\hline$M B L$ & g.1164 G > A (Exon 3) & Proline-Glutamine & $\mathrm{FC}(\%), \mathrm{PC}(\%)$ & Chinese Holstein & China & [154] \\
\hline OLR 1 (BTA5) & SNP10497 A > C (3' UTR) & & PC (\%) & Israeli-Holstein & Israel & [155] \\
\hline PRKG1 (BTA26) & 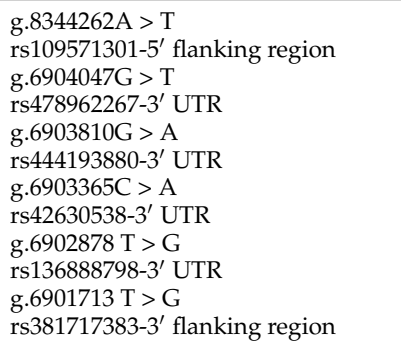 & & MFAs & Chinese Holstein & China & [156] \\
\hline Prolactin (BTA23) & $\begin{array}{l}-1043 \mathrm{~A}>\mathrm{G} \text { (Promoter) } \\
-402 \mathrm{~A}>\mathrm{G} \text { (Promoter) } \\
+8398 \mathrm{G}>\mathrm{A}(\text { Exon } 4)\end{array}$ & & MY, MFC (\%) & Chinese Holstein & China & [96] \\
\hline Prolactin & g.7545G > A(Intron 4) & & MY & Chinese Holstein & China & [97] \\
\hline SCAP (BTA23) & ss526061914 (5-UTR/Exon 1) & & MY, MFAs & Holstein & US & [157] \\
\hline INSIG1 (BTA4) & ss526061846 (Exon 4) & L852P & MY, MFAs & Holstein & US & [157] \\
\hline SREBF1 (BTA19) & ss526061830 (Exon 14) & & MFAs & Holstein & US & [157] \\
\hline SLC27A1(BTA1) & SNP-112T $>C$ & & MY & Chinese Holstein & China & [158] \\
\hline SLC27A6 (BTA1) & $\begin{array}{l}\text { g.390C > T } \\
\text { ss672469900-Exon1 } \\
\text { g.15975T > C } \\
\text { ss672469898-Exon2 }\end{array}$ & & MFAs & Holstein & US & [159] \\
\hline SLC27A6 & $\begin{array}{l}\text { g.242A > T } \\
\text { ss672469901-Exon1 }\end{array}$ & Lysine81methionine & MFAs & Holstein & US & [159] \\
\hline FABP4 (BTA14) & $\begin{array}{l}\text { g.3711G > C } \\
\text { ss672469893-Exon3 } \\
\text { g.3691G > A } \\
\text { ss672469894-Exon3 }\end{array}$ & Valine110Methionine & MFAs & Holstein & US & [159] \\
\hline TLR4 (BTA8) & $\begin{array}{l}\text { c. }-226 \mathrm{G}>\mathrm{C} \\
\text { rs } 29017188 \\
\text { c. } 2021 \mathrm{C}>\mathrm{T} \\
\text { rs } 8193069\end{array}$ & & $\begin{array}{l}\text { MY, FC (\%), PC } \\
(\%), \text { LCA }(\%)\end{array}$ & Chinese Holstein & China & [160] \\
\hline TLR4 & c. $2021 \mathrm{C}>\mathrm{T}$ & $\begin{array}{l}\text { Threonine- } \\
\text { isoleucine }\end{array}$ & MY, FC & Chinese Holstein & China & [161] \\
\hline Lactoferrin (BTA22) & $\begin{array}{l}\text { SNPs }-270 \mathrm{~T}>\mathrm{C} \\
\text { SNP-156 A > G }\end{array}$ & & $\begin{array}{l}\text { FC (\%), PC }(\%), \\
\operatorname{LCA}(\%)\end{array}$ & Chinese Holstein & China & [162] \\
\hline Transferrin (BTA1) & $\begin{array}{l}\text { g.-1748 G > A } \\
\text { ss250608649-5-Flanking region } \\
\text { g.14037A > G } \\
\text { ss250608651-Exon } 8\end{array}$ & & MY, PC (\%) & $\begin{array}{l}\text { China Holstein Luxi } \\
\text { Yellow Bohai Black }\end{array}$ & China & [163] \\
\hline SCL2A12 (BTA1) & g.72224078C > G-5-Flanking region & & $\begin{array}{l}\text { MY, FC (\%), PY, LY, } \\
\text { LC (\%) }\end{array}$ & Polish Holstein & Poland & [164] \\
\hline SCL5A1 (BTA1) & g.70571253A > G (Promoter) & & $\begin{array}{l}\text { MY, FC (\%), PY, LY, } \\
\text { LC }(\%)\end{array}$ & Polish Holstein & Poland & [164] \\
\hline Leptin (BTA4) & rs29004509-exon 3 & & MY & $\begin{array}{l}\text { indicine and taurine } \\
\text { crossbred (Karan Fries) }\end{array}$ & & [165] \\
\hline LALBA (BTA5) & g.31183170T > C-promoter region & & LY, MY & Polish Holstein & Poland & [166] \\
\hline PIK3R1 (BTA20) & $\begin{array}{l}\text { g. } 4453141 \mathrm{~T}>\mathrm{G}-5^{\prime} \text { flanking region } \\
\text { rs207593520 } \\
\text { c. } 1505 \mathrm{G}>\mathrm{A}-3^{\prime} \mathrm{UTR} \\
\text { rs208460068 } \\
\text { g. } 4448024 \mathrm{C}>\mathrm{T}-3^{\prime} \text { flanking region } \\
\text { rs209154772 } \\
\text { g.4447105C > G-3' flanking region } \\
\text { rs210000760 }\end{array}$ & & $\begin{array}{l}\text { MY, FC (\%), PY, FY, } \\
\text { PC }(\%)\end{array}$ & Chinese Holstein & China & {$[6]$} \\
\hline
\end{tabular}


Table 3. Cont.

\begin{tabular}{|c|c|c|c|c|c|c|}
\hline Gene (Location) & Polymorphism (Location) & $\begin{array}{l}\text { Change in Amino } \\
\text { Acid Sequence }\end{array}$ & Production Trait & Breed & Country & Author \\
\hline PIK3R1 (BTA20) & $\begin{array}{l}\text { c. } 208 \mathrm{G}>\mathrm{A}-5^{\prime} \mathrm{UTR} \\
\text { rs42590258 } \\
\text { GG } 0.41 \\
\text { c. } 2776 \mathrm{~T}>\mathrm{C}-3^{\prime} \mathrm{UTR} \\
\text { rs210389799 } \\
\text { c. } 2962 \mathrm{~T}>\mathrm{C}-3^{\prime} \mathrm{UTR} \\
\text { rs208819656 } \\
\text { c.6275 T > A-3'UTR } \\
\text { rs } 41255622 \\
\text { g.11323546C > T-3' flanking region } \\
\text { rs133655926 } \\
\text { g.11323118G > A } \\
\text { rs211408208-3'flanking region }\end{array}$ & & $\begin{array}{l}\text { MY, FC (\%), PY, FY, } \\
\text { PC }(\%)\end{array}$ & & & {$[6]$} \\
\hline GH (BTA19) & GHp.L127V (Exon 5) & & MFAs, MY & Modicana cows & Italy & [167] \\
\hline $\begin{array}{l}\text { TMEM232 (BTA7) } \\
\text { HCN4 (BTA9) } \\
\text { ATP8A2 (BTA12) } \\
\text { LOC524642 (BTA29) } \\
\text { LOC524642 }\end{array}$ & $\begin{array}{l}\text { rs43708473 } \\
\text { rs110025880 } \\
\text { rs109784719 } \\
\text { rs42169108 } \\
\text { rs43099931 }\end{array}$ & & MY & Holstein & Germany & [168] \\
\hline HAL (BTA5) & $\begin{array}{l}\text { ss974768522 (Promoter) } \\
\text { ss974768523 (Exon 1) } \\
\text { ss974768527 (Exon8) } \\
\text { ss974768525 (Exon5) }\end{array}$ & $\begin{array}{l}\text { N42N } \\
\text { I156I } \\
\text { Gly228Glu }\end{array}$ & $\begin{array}{l}\text { Milk production } \\
\text { traits }\end{array}$ & Chinese Holstein & China & [169] \\
\hline GALE (BTA2) & $\begin{array}{l}\text { g. } 2114 \mathrm{~A}>\mathrm{G}-5^{\prime}-\mathrm{UTR} \\
\text { ss1996900612 } \\
\text { g. } 2037 \mathrm{G}>\mathrm{A}-5^{\prime}-\mathrm{UTR} \\
\text { ss1996900613 } \\
\text { g. } 3836 \mathrm{G}>\mathrm{C} \text {-Introm } 9 \\
\text { rs211659075 }\end{array}$ & & MY, FY, PY, PP & Chinese Holstein & China & [170] \\
\hline
\end{tabular}

MY: milk yield; TDMY: Test-day milk yield; PC: Protein content; MFY: Milk fat yield; MFC (\%): Milk fat content (\%); MPTs: Milk protein traits; LY:Lactose Yield; LC: Lactose contents; FP: fat percentage, PY: protein yield, PP: protein percentage, MFA: Milk fatty acids; LC: lactose content; LL: Lactation length; milk medium-chain fatty acids (MCFAs); $3^{\prime}$ untranslated region (UTR); BTA21: Bos Taurus autosomal chromosome 21; Serpin peptidase inhibitor, clade A (SERPINA1); histidine ammonia-lyse gene (HAL); (Sterol regulatory element-binding protein-1 (SREBP1); UDP-galactose-4-epimerase (GALE); acetyl-CoA carboxylase beta (ACACB); SREBP cleavage-activating protein (SCAP); insulin-induced protein 1 (INSIG1);insulin-induced protein 2 (INSIG2); membrane-bound transcription factor protease, site 1 (MBTPS1); membrane-bound transcription factor protease, site 2 (MBTPS2); stearoyl coenzyme-A desaturases (SCD1 and SCD5); thyroid hormoneinducible hepatic protein gene (THRSP); UDP-glucose dehydrogenase (UDPH); Mitogen activated protein kinase kinase kinase kinase (MAP4K4); insulin-like growth factor receptor 2 (IGF2R); fatty acid synthase (FASN); peroxisome proliferator-activated receptor gamma, coactivator 1 alpha (PPARGC1A); ATP-binding cassette, sub-family G, member 2 (ABCG2); insulin-like growth factor 1 (IGF1); leptin receptor (LEPR); 1-acylglycerol-3-phosphate Oacyltransferas 3 (AGPAT3); Conserved helix-loop-helix ubiquitous kinase (CHUK); Multiple inositol-polyphosphate phosphatase 1 (MOGAT1); Multiple inositol-polyphosphate phosphatase 1 (MINPP1); carboxypeptidase M (CPM); enoyl-CoA hydratase, short chain 1 (ECHS1); Fatty acid desaturase 1 (FADS1) and 2(FADS2); lipase family member K (LIPK); lipase family member J (LIPJ); Janus kinase 2 (JAK2); ELOVL6:Fatty Acid Elongase 6; ACSL1:acyl-CoAsynthetase 1; bovine major histocompatibility complex (BoLA); Iso:Isoleucine; Thr: Threonine; Ala: Alanine; Asp: Aspartic acid; CSN3:kappa casein; GHR: growth hormone receptor; HTR1B:hydroxytryptamine receptor 1B; IGF2: Insulin-like growth factor 2; IGFBP2:Insulin-like growth factor binding protein-2; PDE9A:Phosphodiesterase9A; MBL: Mannan-binding lectin; OLR 1: oxidized low-density lipoprotein (lectin-like) receptor 1; PRKG1: protein kinase, cGMP-dependent, type I; SREBF1: sterol regulatory element binding transcription factor 1; SLC27A1: solute carrier family 27 member 1" protein;TLR4: Toll-like receptor 4; LALBA: Alpha-lactalbumin; phosphoinositide-3-kinase regulatory subunit 1 (PIK3R1); dual specificity phosphatase 1 (DUSP1); Growth hormone (GH);Long-chain acyl-CoA synthetase 1 (ACSL1); protein tyrosine kinase 2 (PTK2).

\section{Conclusions}

In the current review, we documented several genes associated with milk production traits in dairy cattle. Moreover, many SNPs within candidate genes were highlighted in the current review, which could be a useful addition to the genetic markers linked to the improvement of milk production traits in dairy cattle. There are still many candidate genes reported through GWAS studies, RNA-seq and DNA-seq need further validation in dairy cattle before selecting them as genetic markers in cattle breeding.

Author Contributions: Conceptualization, Y.M., M.Z.K. and Z.C.; writing-original draft preparation, M.Z.K., Y.M. and Z.C.; data search and collection, T.C., J.W., X.C., Z.H. and M.K.S.; editing and technical review, M.Z.K., J.X., S.L., Y.M., G.M.A. and Z.C.; visualization, Z.C.; supervision, Z.C. All authors have read and agreed to the published version of the manuscript.

Funding: The review was supported by the 2115 Talent Development Program of China Agricultural University. The funder had no role in the study design, data collection, analysis, decision to publish, and manuscript preparation. 
Informed Consent Statement: Informed consent was obtained from all subjects involved in the study.

Data Availability Statement: All the data are already provided in the main manuscript. Contact the corresponding author if further explanation is required.

Acknowledgments: We acknowledge the National Key Research and Development Program of China (2018YFD0501600), the national natural science foundation of China (U20A2062) and S \& T Program of Hebei (19226625D) for their financial support. We also acknowledge the China Agricultural University, Beijing, China, for providing us with an environment of learning. Without this platform, the completion of this work would not have been an easy task.

Conflicts of Interest: The authors declare no conflict of interest.

\section{References}

1. Khan, M.Z.; Wang, D.; Liu, L.; Usman, T.; Wen, H.; Zhang, R.; Liu, S.; Shi, L.; Mi, S.; Xiao, W.; et al. Significant genetic effects of JAK2 and DGAT1 mutations on milk fat content and mastitis resistance in Holsteins. J. Dairy Res. 2019, 86, 388-393. [CrossRef]

2. Khan, M.Z.; Liu, L.; Zhang, Z.; Khan, A.; Wang, D.; Mi, S.; Usman, T.; Liu, G.; Guo, G.; Li, X.; et al. Folic acid supplementation regulates milk production variables, metabolic associated genes and pathways in perinatal Holsteins. J. Anim. Physiol. Anim. Nutr. 2020, 104, 483-492. [CrossRef]

3. Chen, S.; Menglin, C.; Chen, T.; Yuzhuang, L.; Tian, D.; Hui, W.; Xiaolin, L. Genetic variants of fatty acid elongase 6 in Chinese Holstein cow. Gene 2017, 670, 123-129. [CrossRef]

4. Qian, L.; Zhao, A.; Zhang, Y.; Chen, T.; Zeisel, S.H.; Jia, W.; Cai, W. Metabolomic Approaches to Explore Chemical Di-versity of Human Breast-Milk, Formula Milk and Bovine Milk. Int. J. Mol. Sci. 2016, 17, 2128. [CrossRef] [PubMed]

5. Ibeagha-Awemu, E.M.; Kgwatalala, P.; Zhao, X. A critical analysis of production-associated DNA polymorphisms in the genes of cattle, goat, sheep, and pig. Mamm. Genome 2008, 19, 591-617. [CrossRef]

6. Han, B.; Yuan, Y.; Shi, L.; Li, Y.; Liu, L.; Sun, D. Identification of single nucleotide polymorphisms of PIK3R1 and DUSP1 genes and their genetic associations with milk production traits in dairy cows. J. Anim. Sci. Biotechnol. 2019, 10, 81. [CrossRef] [PubMed]

7. Laodim, T.; Elzo, M.A.; Koonawootrittriron, S.; Suwanasopee, T.; Jattawa, D. Genomic-polygenic and polygenic predictions for milk yield, fat yield, and age at first calving in Thai multibreed dairy population using genic and functional sets of genotypes. Livest. Sci. 2019, 219, 17-24. [CrossRef]

8. Grisart, B.; Coppieters, W.; Farnir, F.; Karim, L.; Ford, C.; Berzi, P.; Cambisano, N.; Mni, M.; Reid, S.; Simon, P.; et al. Positional Candidate Cloning of a QTL in Dairy Cattle: Identification of a Missense Mutation in the Bovine DGAT1 Gene with Major Effect on Milk Yield and Composition. Genome Res. 2002, 12, 222-231. [CrossRef] [PubMed]

9. Grisart, B.; Farnir, F.; Karim, L.; Cambisano, N.; Kim, J.-J.; Kvasz, A.; Mni, M.; Simon, P.; Frere, J.-M.; Coppieters, W.; et al. Genetic and functional confirmation of the causality of the DGAT1 K232A quantitative trait nucleotide in affecting milk yield and composition. Proc. Natl. Acad. Sci. USA 2004, 101, 2398-2403. [CrossRef]

10. Cui, X.; Yali, H.; Shaohua, Y.; Yan, X.; Shengli, Z.; Yuan, Z.; Qin, Z.; Xuemei, L.; George, E.L.; Dongxiao, S. Transcriptional profiling of mammary gland in Holstein cows with extremely different milk protein and fat percentage using RNA sequencing. BMC Genom. 2014, 15, 226. [CrossRef]

11. Boutinaud, M.; Galio, L.; Lollivier, V.; Finot, L.; Wiart, S.; Esquerre, D.; Devinoy, E. Unilateral once daily milking locally induces differential gene expression in both mammary tissue and milk epithelial cells revealing mammary remodeling. Physiol. Genom. 2013, 45, 973-985. [CrossRef] [PubMed]

12. Nayeri, S.; Sargolzaei, M.; Abo-Ismail, M.K.; May, N.; Miller, S.P.; Schenkel, F.; Moore, S.; Stothard, P. Genome-wide association for milk production and female fertility traits in Canadian dairy Holstein cattle. BMC Genet. 2016, 17, 75. [CrossRef] [PubMed]

13. Olsen, H.G.; Hayes, B.J.; Kent, M.P.; Nome, T.; Svendsen, M.; Larsgard, A.G.; Lien, S. Genome-wide association mapping in Norwegian Red cattle identifies quantitative trait loci for fertility and milk production on BTA12. Anim. Genet. 2011, 42, 466-474. [CrossRef]

14. Cole, J.B.; Wiggans, G.R.; Ma, L.; Sonstegard, T.S.; Lawlor, T.J., Jr.; Crooker, B.A.; Van Tassell, C.P.; Yang, J.; Wang, S.; Matukumalli, L.K.; et al. Genome-wide association analysis of thirty one production, health, reproduction and body conformation traits in contemporary U.S. Holstein cows. BMC Genom. 2011, 12, 408. [CrossRef]

15. Li, Y.; Han, B.; Liu, L.; Zhao, F.; Liang, W.; Jiang, J.; Yang, Y.; Ma, Z.; Sun, D. Genetic association of DDIT3, RPL23A, SESN2 and NR4A1 genes with milk yield and composition in dairy cattle. Anim. Genet. 2018, 50, 123-135. [CrossRef]

16. Chamberlain, A.J.; Hayes, B.J.; Savin, K.; Bolormaa, S.; McPartlan, H.C.; Bowman, P.J.; Van Der Jagt, C.; MacEachern, S.; Goddard, M.E. Validation of single nucleotide polymorphisms associated with milk production traits in dairy cattle. J. Dairy sci. 2012, 95, 864-875. [CrossRef] [PubMed]

17. Bouwman, A.C.; Bovenhuis, H.; Visker, M.H.; Van Arendonk, J.A. Genome-wide association of milk fatty acids in Dutch dairy cattle. BMC Genet. 2011, 12, 43. [CrossRef] [PubMed]

18. Schopen, G.; Visker, M.; Koks, P.; Mullaart, E.; van Arendonk, J.; Bovenhuis, H. Whole-genome association study for milk protein composition in dairy cattle. J. Dairy Sci. 2011, 94, 3148-3158. [CrossRef] [PubMed] 
19. Meredith, B.K.; Kearney, J.F.; Finlay, K.E.; Bradley, G.D.; Fahey, G.A.; Berry, P.D.; Lynn, J.D. Genome-wide associations for milk production and somatic cell score in Holstein-Friesian cattle in Ireland. BMC Genet. 2013, 13, 21. [CrossRef] [PubMed]

20. Tribout, T.; Croiseau, P.; Lefebvre, R.; Barbat, A.; Boussaha, M.; Fritz, S.; Boichard, D.; Hoze, C.; Sanchez, M.-P. Confirmed effects of candidate variants for milk production, udder health, and udder morphology in dairy cattle. Genet. Sel. Evol. 2020, 52, 55. [CrossRef]

21. Jiang, J.; Liu, L.; Gao, Y.; Shi, L.; Li, Y.; Liang, W.; Sun, D. Determination of genetic associations between indels in 11 candidate genes and milk composition traits in Chinese Holstein population. BMC Genet. 2019, 20, 48. [CrossRef] [PubMed]

22. Sanchez, M.; Armelle, G.; Pascal, C.; Sébastien, F.; Chris, H.; Guy, M.; Marton, P.; Barbet-Leterrier, S.; Letaief, R.; Rocha, D.; et al. Within-breed and multi-breed GWAS on imputed whole-genome sequence variants reveal candidate mutations affecting milk protein composition in dairy cattle. Genet. Sel. Evol. 2017, 49, 68. [CrossRef] [PubMed]

23. Iung, L.H.S.; Petrini, J.; Ramírez-Díaz, J.; Salvian, M.; Rovadoscki, G.A.; Pilonetto, F.; Dauria, B.D.; Machado, P.F.; Coutinho, L.L.; Wiggans, G.R.; et al. Genome-wide association study for milk production traits in a Brazilian Holstein popula-tion. J. Dairy Sci. 2019, 102, 1-10. [CrossRef]

24. Atashi, H.; Salavati, M.; De Koster, J.; Ehrlich, J.; Crowe, M.; Opsomer, G.; McLoughlin, N.; Hostens, M.; Fahey, A.; Matthews, E.; et al. Genome-wide association for milk production and lactation curve parameters in Holstein dairy cows. J. Anim. Breed. Genet. 2019, 137, 292-304. [CrossRef]

25. Buitenhuis, B.; Janss, L.L.G.; Poulsen, N.A.; Larsen, L.B.; Larsen, M.K.; Sørensen, P. Genome-wide association and biological pathway analysis for milk-fat composition in Danish Holstein and Danish Jersey cattle. BMC Genom. 2014, 15, 1112. [CrossRef]

26. Ning, C.; Wang, D.; Zheng, X.; Zhang, Q.; Zhang, S.; Mrode, R.; Liu, J.-F. Eigen decomposition expedites longitudinal genome-wide association studies for milk production traits in Chinese Holstein. Genet. Sel. Evol. 2018, 50, 12. [CrossRef] [PubMed]

27. Wang, D.; Ning, C.; Liu, J.-F.; Zhang, Q.; Jiang, L. Replication of genome-wide association studies for milk production traits in Chinese Holstein by an efficient rotated linear mixed model. J. Dairy Sci. 2019, 102, 2378-2383. [CrossRef]

28. Poulsen, N.A.; Robinson, R.C.; Barile, D.; Larsen, L.B.; Buitenhuis, B. A genome-wide association study reveals specific transferases as candidate loci for bovine milk oligosaccharides synthesis. BMC Genom. 2019, 20, 404. [CrossRef]

29. Ariyarathne, H.; Correa-Luna, M.; Blair, H.; Garrick, D.; Lopez-Villalobos, N. Identification of Genomic Regions Associated with Concentrations of Milk Fat, Protein, Urea and Efficiency of Crude Protein Utilization in Grazing Dairy Cows. Genes 2021, 12, 456. [CrossRef]

30. Li, C.; Sun, D.; Zhang, S.; Wang, S.; Wu, X.; Zhang, Q.; Liu, L.; Li, Y.; Qiao, L. Genome Wide Association Study Identifies 20 Novel Promising Genes Associated with Milk Fatty Acid Traits in Chinese Holstein. PLoS ONE 2014, 9, e96186. [CrossRef]

31. Zhou, J.; Liyuan, L.; Chunpeng, C.; Menghua, Z.; Xin, L.; Zhiwu, Z.; Xixia, H.; Yuangang, S. Genome-wide association study of milk and reproductive traits in dual-purpose Xinjiang Brown cattle. BMC Genom. 2019, 20, 827. [CrossRef]

32. Jiang, L.; Liu, J.-F.; Sun, D.; Ma, P.; Ding, X.; Yu, Y.; Zhang, Q. Genome Wide Association Studies for Milk Production Traits in Chinese Holstein Population. PLoS ONE 2010, 5, e13661. [CrossRef]

33. Kolbehdari, D.; Wang, Z.; Grant, J.R.; Murdoch, B.; Prasad, A.; Xiu, Z.; Marques, E.; Stothard, P.; Moore, S.S. A whole genome scan to map QTL for milk production traits and somatic cell score in Canadian Holstein bulls. J. Anim. Breed. Genet. 2009, 126, $216-227$. [CrossRef] [PubMed]

34. da Cruz, A.S.; Silva, D.C.; Minasi, L.B.; Teixeira, L.K.d.F.; Rodrigues, F.M.; da Silva, C.C.; Carmo, A.S.D.; da Silva, M.V.G.B.; Utsunomiya, Y.T.; Garcia, J.F.; et al. Single-Nucleotide Polymorphism Variations Associated with Specific Genes Putatively Identified Enhanced Genetic Predisposition for 305-Day Milk Yield in the Girolando Crossbreed. Front. Genet. 2021, 11. [CrossRef] [PubMed]

35. Yue, S.J.; Zhao, Y.Q.; Gu, X.R.; Yin, B.; Jiang, Y.L.; Wang, Z.H.; Shi, K.R. A genome-wide association study suggests new candidate genes for milk production traits in Chinese Holstein cattle. Anim. Genet. 2017, 48, 677-681. [CrossRef]

36. Liu, L.; Jinghang, Z.; Chunpeng, C.; Juan, Z.; Wan, W.; Jia, T.; Zhiwu, Z.; Yaling, G. GWAS-Based Identification of New Loci for Milk Yield, Fat, and Protein in Holstein Cattle. Animals 2020, 10, 2048. [CrossRef] [PubMed]

37. Kim, S.; Lim, B.; Cho, J.; Lee, S.; Dang, C.-G.; Jeon, J.-H.; Kim, J.-M.; Lee, J. Genome-Wide Identification of Candidate Genes for Milk Production Traits in Korean Holstein Cattle. Animals 2021, 11, 1392. [CrossRef]

38. Pegolo, S.; Cecchinato, A.; Mele, M.; Conte, G.; Schiavon, S.; Bittante, G. Effects of candidate gene polymorphisms on the detailed fatty acids profile determined by gas chromatography in bovine milk. J. Dairy Sci. 2016, 99, 4558-4573. [CrossRef]

39. Li, X.; Buitenhuis, A.; Lund, M.; Li, C.; Sun, D.; Zhang, Q.; Poulsen, N.; Su, G. Joint genome-wide association study for milk fatty acid traits in Chinese and Danish Holstein populations. J. Dairy Sci. 2015, 98, 8152-8163. [CrossRef]

40. Otto, I.P.; Simone, E.F.; Guimarães, M.P.L.; Calus, J.V.; Marco, A.; Machado, J.C.; Panetto, C.; da Silva Marcos Vinícius, G.B. Single-step genome-wide association studies (GWAS) and post-GWAS analyses to identify genomic regions and candidate genes for milk yield in Brazilian Girolando cattle. J. Dairy Sci. 2020, 103, 10347-10360. [CrossRef]

41. Bagnato, A.; Schiavini, F.; Rossoni, A.; Maltecca, C.; Dolezal, M.; Medugorac, I.; Sölkner, J.; Russo, V.; Fontanesi, L.; Friedmann, A.; et al. Quantitative Trait Loci Affecting Milk Yield and Protein Percentage in a Three-Country Brown Swiss Population. J. Dairy Sci. 2008, 91, 767-783. [CrossRef] [PubMed]

42. Ouattara, B.; Bissonnette, N.; Duplessis, M.; Girard, C.L. Supplements of vitamins B9 and B12 affect hepatic and mammary gland gene expression profiles in lactating dairy cows. BMC Genom. 2016, 17, 640. [CrossRef] [PubMed] 
43. Li, Q.; Ruobing, L.; Yan, L.; Yanxia, G.; Qiufeng, L.; Dongxiao, S.; Jianguo, L. Identification of candidate genes for milk pro-duction traits by RNA sequencing on bovine liver at different lactation stages. BMC Genet. 2020, 21, 72. [CrossRef]

44. Bai, X.; Zhuqing, Z.; Bin, L.; Xiaoyang, J.; Yongsheng, B.; Wenguang, Z. Whole blood transcriptional profiling comparison between different milk yield of Chinese Holstein cows using RNA-seq data. BMC Genom. 2016, 17, 512. [CrossRef]

45. Li, C.; Wentao, C.; Chenghao, Z.; Hongwei, Y.; Ziqi, Z.; Juan, J.L.; Dongxiao, S.; Qin, Z.; Jianfeng, L.; Shengli, Z. RNA-Seq reveals 10 novel promising candidate genes affecting milk protein concentration in the Chinese Holstein population. Sci. Rep. 2016, 6, 26813. [CrossRef] [PubMed]

46. Zhou, C.; Shen, D.; Li, C.; Cai, W.; Liu, S.; Yin, H.; Shi, S.; Cao, M.; Zhang, S. Comparative Transcriptomic and Proteomic Analyses Identify Key Genes Associated with Milk Fat Traits in Chinese Holstein Cows. Front. Genet. 2019, 10, 672. [CrossRef]

47. Dai, W.; Wang, Q.; Zhao, F.; Liu, J.; Liu, H. Understanding the regulatory mechanisms of milk production using integrative transcriptomic and proteomic analyses: Improving inefficient utilization of crop by-products as forage in dairy industry. BMC Genom. 2018, 19, 403. [CrossRef]

48. Lin, Y.; Lv, H.; Jiang, M.; Zhou, J.; Song, S.; Hou, X. Functional analysis of the dairy cow mammary transcriptome between early lactation and mid-dry period. J. Dairy Res. 2019, 86, 63-67. [CrossRef]

49. Yang, J.; Jiang, J.; Liu, X.; Wang, H.; Guo, G.; Zhang, Q.; Jiang, L. Differential expression of genes in milk of dairy cattle during lactation. Anim. Genet. 2015, 47, 174-180. [CrossRef]

50. Peterson, B.K.; Weber, J.; Kay, E.H.; Fisher, H.S.; Hoekstra, H. Double Digest RADseq: An Inexpensive Method for De Novo SNP Discovery and Genotyping in Model and Non-Model Species. PLoS ONE 2012, 7, e37135. [CrossRef]

51. Weldenegodguad, M.; Popov, R.; Pokharel, K.; Ammosov, I.; Ming, Y.; Ivanova, Z.; Kantanen, J. Whole-Genome Sequencing of Three Native Cattle Breeds Originating from the Northernmost Cattle Farming Regions. Front. Genet. 2019, 9, 728. [CrossRef] [PubMed]

52. Rosse, I.C.; Assis, J.G.; Oliveira, F.S.; Leite, L.R.; Araujo, F.; Zerlotini, A.; Volpini, A.; Dominitini, A.J.; Lopes, B.C.; Arbex, W.A.; et al. Whole genome sequencing of Guzerá cattle reveals genetic variants in candidate genes for production, disease resistance, and heat tolerance. Mamm. Genome 2017, 28, 66-80. [CrossRef] [PubMed]

53. Sigdel, A.; Abdollahi-Arpanahi, R.; Aguilar, I.; Peñagaricano, F. Whole Genome Mapping Reveals Novel Genes and Pathways Involved in Milk Production Under Heat Stress in US Holstein Cows. Front. Genet. 2019, 10. [CrossRef]

54. Nanaei, H.A.; Qanatqestani, M.D.; Esmailizadeh, A. Whole-genome resequencing reveals selection signatures associated with milk production traits in African Kenana dairy zebu cattle. Genomics 2019, 112, 880-885. [CrossRef] [PubMed]

55. Ye, M.; Xu, M.; Lu, M.; Zhou, B.; El-Kader, H.A.; Alam, S.S.; Mahrous, K.F. Identification of candidate genes associated with milk yield trait in buffaloes (Bubalus bubalis) by restriction-site-associated DNA sequencing. Rev. Bras. Zootec. 2020, 49. [CrossRef]

56. Iso-Touru, T.; Sahana, G.; Guldbrandtsen, B.; Lund, M.S.; Vilkki, J. Genome-wide association analysis of milk yield traits in Nordic Red Cattle using imputed whole genome sequence variants. BMC Genet. 2016, 17, 55. [CrossRef]

57. Schennink, A.; Heck, J.M.; Bovenhuis, H.; Visker, M.H.P.W.; Van Valenberg, H.J.F.; Van Arendonk, J.A.M. Milk fatty acid unsaturation: Genetic parameters and effects of Stearoyl-CoA Desaturase (SCD1) and Acyl-CoA: Diacylglicerol Acylotrans-ferase (DGAT1). J. Dairy Sci. 2008, 91, 2135-2143. [CrossRef] [PubMed]

58. Conte, G.; Mele, M.; Chessa, S.; Castiglioni, B.; Serra, A.; Pagnacco, G.; Secchiari, P. Diacylglycerol acyltransferase 1, stearoyl-CoA desaturase 1 , and sterol regulatory element binding protein 1 gene polymorphisms and milk fatty acid composition in Italian Brown cattle. J. Dairy Sci. 2010, 93, 753-763. [CrossRef]

59. Mele, M.; Conte, G.; Castiglioni, B.; Chessa, S.; Macciotta, N.P.P.; Serra, A.; Buccioni, A.; Pagnacco, G.; Secchiari, P. Stearoyl-Coenzyme A Desaturase Gene Polymorphism and Milk Fatty Acid Composition in Italian Holsteins. J. Dairy Sci. 2007, 90, 4458-4465. [CrossRef]

60. Taniguchi, M.; Utsugi, T.; Oyama, K.; Mannen, H.; Kobayashi, M.; Tanabe, Y.; Ogino, A.; Tsuji, S. Genotype of stearoyl-CoA desaturase is associated with fatty acids composition in Japanese Black cattle. Mamm. Genom. 2004, 14, 142-148. [CrossRef]

61. Macciotta, N.P.P.; Mele, M.; Conte, G.; Serra, A.; Cassandro, M.; Dal Zotto, R.; Borlino, A.C.; Pagnacco, G.; Secchiari, P. As-sociation between a polymorphism at the stearoyl CoA desaturase locus and milk production traits in Italian Holsteins. J. Dairy Sci. 2008, 91, 3184-3189. [CrossRef]

62. Kgwatala, P.M.; Ibeagha-Awemu, M.E.; Hayes, F.J.; Zhao, X. Stearoyl-CoA desaturase 1 3'UTR SNPs and their influence on milk fatty acid composition of Canadian Holstein cows. J. Anim. Breed. Genet. 2009, 126, 394-403. [CrossRef] [PubMed]

63. Alim, A.M.; Dong, T.; Xie, Y.; Wu, X.P.; Zhang, Y.; Shengli, Z.; Sun, X.D. Effect of polymorphisms in the CSN3 (j-casein) gene on milk production traits in Chinese Holstein Cattle. Mol. Biol. Rep. 2014, 41, 7585-7593. [CrossRef] [PubMed]

64. Kęsek-Woźniak, M.M.; Wojtas, E.; Zielak-Steciwko, A.E. Impact of SNPs in ACACA, SCD1, and DGAT1 Genes on Fatty Acid Profile in Bovine Milk with Regard to Lactation Phases. Animals 2020, 10, 997. [CrossRef]

65. Duchemin, S.; Bovenhuis, H.; Stoop, W.; Bouwman, A.; Van Arendonk, J.; Visker, M. Genetic correlation between composition of bovine milk fat in winter and summer, and DGAT1 and SCD1 by season interactions. J. Dairy Sci. 2013, 96, 592-604. [CrossRef]

66. Houaga, I.; Muigai, A.W.T.; Ng'Ang'A, F.M.; Ibeagha-Awemu, E.M.; Kyallo, M.; Youssao, I.A.K.; Stomeo, F. Milk fatty acid variability and association with polymorphisms in SCD1 and DGAT1 genes in White Fulani and Borgou cattle breeds. Mol. Biol. Rep. 2018, 45, 1849-1862. [CrossRef] [PubMed]

67. Carvajal, A.; Huircan, P.; Dezamour, J.; Subiabre, I.; Kerr, B.; Morales, R.; Ungerfeld, E. Milk fatty acid profile is modulated by DGAT1 and SCD1 genotypes in dairy cattle on pasture and strategic supplementation. Genet. Mol. Res. 2016, 15. [CrossRef] 
68. Bovenhuis, H.; Visker, M.; Poulsen, N.; Sehested, J.; Van Valenberg, H.; van Arendonk, J.; Larsen, L.B.; Buitenhuis, A. Effects of the diacylglycerol o-acyltransferase 1 (DGAT1) K232A polymorphism on fatty acid, protein, and mineral composition of dairy cattle milk. J. Dairy Sci. 2016, 99, 3113-3123. [CrossRef] [PubMed]

69. Tzompa-Sosa, D.A.; van Aken, G.A.; van Hooijdonk, A.C.M.; van Valenberg, H.J.F. Influence of C16:0 and long-chain sat-urated fatty acids on normal variation of bovine milk fat triacylglycerol structure. J. Dairy Sci. 2014, 97, 4542-4551. [CrossRef] [PubMed]

70. Vanbergue, E.; Peyraud, J.; Guinard-Flament, J.; Charton, C.; Barbey, S.; Lefebvre, R.; Gallard, Y.; Hurtaud, C. Effects of DGAT1 K232A polymorphism and milking frequency on milk composition and spontaneous lipolysis in dairy cows. J. Dairy Sci. 2016, 99, 5739-5749. [CrossRef] [PubMed]

71. Van Gastelen, S.; Visker, M.; Edwards, J.; Antunes-Fernandes, E.; Hettinga, K.; Alferink, S.; Hendriks, W.; Bovenhuis, H.; Smidt, H.; Dijkstra, J. Linseed oil and DGAT1 K232A polymorphism: Effects on methane emission, energy and nitrogen metabolism, lactation performance, ruminal fermentation, and rumen microbial composition of Holstein-Friesian cows. J. Dairy Sci. 2017, 100, 8939-8957. [CrossRef]

72. Mach, N.; Blum, Y.; Bannink, A.; Causeur, D.; Houee-Bigot, M.; Lagarrigue, S.; Smits, M.A. Pleiotropic effects of polymorphism of the gene diacylglycerol-O-transferase 1 (DGAT1) in the mammary gland tissue of dairy cows. J. Dairy Sci. 2012, 95, 4989-5000. [CrossRef]

73. Raschia, A.M.; Juan, P.N.; Daniel, O.M.; María, J.B.; Ariel, A. Single nucleotide polymorphisms in candidate genes associated with milk yield in Argentinean Holstein and Holstein $\times$ Jersey cows. J. Anim. Sci. Technol. 2018, 60, 31. [CrossRef]

74. Magotra, A.; Gupta, I.D.; Tavsief, A.; Rani, A. Polymorphism in DNA repair gene BRCA1 associated with clinical mastitis and production traits in indigenous dairy cattle. Res. Vet. Sci. 2020, 133, 194-201. [CrossRef]

75. Li, M.; Lu, X.; Gao, Q.; Wang, M.; Arbab, A.A.I.; Sun, Y.; Chen, Z.; Zhang, H.; Karrow, N.A.; Yang, Z.; et al. A Functional 3' UTR Polymorphism of FADS2 Affects Cow Milk Composition through Modifying Mir-744 Binding. Animals 2019, 9, 1090. [CrossRef] [PubMed]

76. Ibeagha-Awemu, E.M.; Akwanji, K.A.; Beaudoin, F.; Zhao, X. Associations between variants of FADS genes and omega-3 and omega-6 milk fatty acids of Canadian Holstein cows. BMC Genet. 2014, 15, 25. [CrossRef]

77. Proskura, W.S.; Liput, M.; Zaborski, D.; Sobek, Z.; Yu, Y.-H.; Cheng, Y.-H.; Dybus, A. The effect of polymorphism in the FADS2 gene on the fatty acid composition of bovine milk. Arch. Anim. Breed. 2019, 62, 547-555. [CrossRef] [PubMed]

78. Ahmed, S.A.; Rahmatalla, S.R.; Bortfeldt, D.; Arends, M.; Reissmann, G.A. Milk protein polymorphisms and casein haplotypes in Butana cattle. J. Appl. Genet. 2017, 58, 261-271. [CrossRef] [PubMed]

79. Gallinat, J.L.; Qanbari, S.; Drögemüller, C.; Pimentel, E.C.; Thaller, G.; Tetens, J. DNA-based identification of novel bovine casein gene variants. J. Dairy Sci. 2013, 96, 699-709. [CrossRef]

80. Tetens, J.L.; Qanbari, S.; Drögemüller, C.; Pimentel, E.C.; Bennewitz, J.; Thaller, G.; Tetens, J. Bos indicus introgression into (peri-)alpine cattle breeds-Evidence from the analysis of bovine whey protein variants. Anim. Genet. 2014, 45, 585-588. [CrossRef]

81. Miluchová, M.; Michal, G.; Juraj, C.; Anna, T.; Kristína, C. Association of HindIII-polymorphism in kappa-casein gene with milk, fat and protein yield in Holstein cattle. Acta Biochim. Pol. 2018, 65, 403-407. [CrossRef] [PubMed]

82. Haruna, I.; Yunhai, L.; Ugonna, J.; Hamed, A.; Huitong, Z.; Jon, G. Associations between the Bovine Myostatin Gene and Milk Fatty Acid Composition in New Zealand Holstein-Friesian $\times$ Jersey-Cross Cows. Animal 2020, 10, 1447. [CrossRef]

83. Zhou, H.; Cheng, P.; Azimu, W.; Hodge, S.; Edwards, G.; Hickford, J.G.H. Variation in the bovine FABP4 gene affects milk yield and milk protein content in dairy cows. Sci. Rep. 2015, 5, 10023. [CrossRef]

84. Jiang, L.; Liu, X.; Yang, J.; Wang, H.; Jiang, J.; Liu, L.; He, S.; Ding, X.; Liu, J.; Zhang, Q. Targeted resequencing of GWAS loci reveals novel genetic variants for milk production traits. BMC Genom. 2014, 15, 1105. [CrossRef]

85. Yang, J.; Liu, X.; Wang, D.; Ning, C.; Wang, H.; Zhang, Q.; Jiang, L. Functional validation of GPIHBP1 and identification of a functional mutation in GPIHBP1 for milk fat traits in dairy cattle. Sci. Rep. 2017, 7, 1-10. [CrossRef]

86. Dong, W.; Jie, Y.; Qin, Z.; Li, J. Role of GPIHBP1 in regulating milk protein traits in dairy cattle. Anim. Biotechnol. 2018, 31, 81-85. [CrossRef] [PubMed]

87. Bionaz, M.; Loor, J.J. ACSL1, AGPAT6, FABP3, LPINI, and SLC27A6 are the most abundant isoforms in bovine mammary tissue and their expression is affected by stage of lactation. J. Nutr. 2008, 138, 1019-1024. [CrossRef]

88. Bionaz, M.; Loor, J.J. Gene Networks Driving Bovine Mammary Protein Synthesis during the Lactation cycle. Bioinform. Biol. Insights 2011, 5, 83-98. [CrossRef]

89. Zhao, Z.D.; Tian, H.S.; Jiang, Y.Y.; Shi, B.G.; Liu, X.; Li, X.P.; Wang, D.Z.; Chen, J.L.; Hu, J. Association analysis of ACSL1 gene promoter polymorphism and dairy quality traits in yak. J. Agric. Biol. 2019, 27, 1596-1630.

90. Fan, Y.; Han, Z.; Lu, X.; Zhang, H.; Idriss Arbab, A.A.; Loor, J.J.; Yang, Y.; Yang, Z. Identification of Milk Fat Metabolism-Related Pathways of the Bovine Mammary Gland during Mid and Late Lactation and Functional Verification of the ACSL4 Gene. Genes 2020, 11, 1357. [CrossRef]

91. Olsen, H.G.; Knutsen, T.M.; Kohler, A.; Svendsen, M.; Gidskehaug, L.; Grove, H.; Nome, T.; Sodeland, M.; Sundsaasen, K.K.; Kent, M.P.; et al. Genome-wide association mapping for milk fat composition and fine mapping of a QTL for de novo synthesis of milk fatty acids on bovine chromosome 13. Genet. Sel. Evol. 2017, 49, 20. [CrossRef] 
92. Wang, X.; Wurmser, C.; Pausch, H.; Jung, S.; Reinhardt, F.; Tetens, J.; Thaller, G.; Fries, R. Identification and Dissection of Four Major QTL Affecting Milk Fat Content in the German Holstein-Friesian Population. PLoS ONE 2012, 7, e40711. [CrossRef] [PubMed]

93. Sun, X.; Liang, Y.; Gao, Q.; Guo, J.; Tang, C.; Shi, K.; Yang, Z.; Mao, Y. AGPAT3 Gene polymorphisms are associated with milk production traits in Chinese Holstein cows. J. Dairy Res. 2021, 88, 247-252. [CrossRef] [PubMed]

94. Shi, L.; Wu, X.; Yang, Y.; Ma, Z.; Lv, X.; Liu, L.; Li, Y.; Zhao, F.; Han, B.; Sun, D. A post-GWAS confirming the genetic effects and functional polymorphisms of AGPAT3 gene on milk fatty acids in dairy cattle. J. Anim. Sci. Biotechnol. 2021, 12, 24. [CrossRef]

95. Littlejohn, M.D.; Tiplady, K.; Lopdell, T.; Law, T.A.; Scott, A.; Harland, C.; Sherlock, R.; Henty, K.; Obolonkin, V. Expression Variants of the Lipogenic AGPAT6 Gene Affect Diverse Milk Composition Phenotypes in Bos taurus. PLoS ONE 2014, 9, e85757. [CrossRef]

96. Lu, A.; Xiucai, H.; Hong, C.; Jihong, J.; Chunlei, Z.; Haixia, X.; Xueyuan, G. Single nucleotide polymorphisms in bovine PRL gene and their associations with milk production traits in Chinese Holsteins. Mol. Biol. Rep. 2010, 37, 547-551. [CrossRef]

97. Dong, H.C.; Song, X.M.; Zhang, L.; Jiang, J.F.; Zhou, J.P.; Jiang, Y.Q. New insights into the prolactin-RsaI (PRL-RsaI) locus in Chinese Holstein cows and its effect on milk performance traits. Genet. Mol. Res. 2013, 12, 5766-5773. [CrossRef]

98. Pegolo, S.; Dadousis, C.; Mach, N.; Ramayo-Caldas, Y.; Mele, M.; Conte, G.; Schiavon, S.; Bittante, G.; Cecchinato, A. SNP co-association and network analyses identify E2F3, KDM5A and BACH2 as key regulators of the bovine milk fatty acid profile. Sci. Rep. 2017, 7, 17317. [CrossRef]

99. Li, C.; Wentao, C.; Shuli, L.; Chenghao, Z.; Hongwei, Y.; Dongxiao, S.; Shengli, Z. SERPINA1 gene identified in RNA-Seq showed strong association with milk protein concentration in Chinese Holstein cows. PeerJ 2020, 8, e8460. [CrossRef]

100. Li, Y.; Huitong, Z.; Long, C.; Jenny, Z.; Jonathan, H. Variation in the stearoyl-CoA desaturase gene (SCD) and its influence on milk fatty acid composition in late-lactation dairy cattle grazed on pasture. Arch. Anim. Breed 2020, 63, 355-366.

101. Alim, A.M.; Dong, T.; Xie, Y.; Zhang, S.L.; Zhang, D.X.; Sun, Q.; Zhang, L.; Liu, L.; Guo, G. Genetic effects of stearoyl-CoA desaturase 1 (SCD1) polymorphism on milk production traits in the Chinese dairy population. Mol. Biol. Rep. 2012, 39, 8733-8740. [CrossRef]

102. Soyeurt, H.; Gillon, A.; Vanderick, S.; Mayeres, P.; Bertozzi, C.; Gengler, N. Estimation of Heritability and Genetic Correlations for the Major Fatty Acids in Bovine Milk. J. Dairy Sci. 2007, 90, 4435-4442. [CrossRef] [PubMed]

103. He, Y.; Chu, Q.; Ma, P.; Wang, Y.; Zhang, Q.; Sun, D.; Zhang, Y.; Yu, Y.; Zhang, Y. Association of bovine CD4 and STAT5b single nucleotide polymorphisms with somatic cell scores and milk production traits in Chinese Holsteins. J. Dairy Res. 2011, 78, 242-249. [CrossRef]

104. Wang, H.; Jiang, L.; Liu, X.; Yang, J.; Wei, J. A Post-GWAS Replication Study Confirming the PTK2 Gene Associated with Milk Production Traits in Chinese Holstein. PLoS ONE 2013, 8, e83625. [CrossRef] [PubMed]

105. Xu, Q.; Gui, M.; Sun, D.; Qin, Z.; Yuan, Z.; Yin, C.; Chen, H.; Ding, X.; Liu, J. Detection of genetic association and functional polymorphisms of UGDH affecting milk production trait in Chinese Holstein cattle. BMC Genom. 2012, 13, 590. [CrossRef] [PubMed]

106. Yang, S.; Gao, Y.; Zhang, S.; Zhang, Q.; Sun, D. Identification of Genetic Associations and Functional Polymorphisms of SAA1 Gene Affecting Milk Production Traits in Dairy Cattle. PLoS ONE 2016, 11, e0162195. [CrossRef] [PubMed]

107. Yang, S.; Li, C.; Xie, Y.; Cui, X.; Li, X.; Wei, J.; Zhang, Y.; Yu, Y.; Wang, Y.; Zhang, S.; et al. Detection of functional polymorphisms influencing the promoter activity of theSAA2gene and their association with milk production traits in Chinese Holstein cows. Anim. Genet. 2015, 46, 591-598. [CrossRef] [PubMed]

108. Han, B.; Liang, W.; Liu, L.; Li, Y.; Sun, D. Genetic association of the ACACB gene with milk yield and composition traits in dairy cattle. Anim. Genet. 2018, 49, 169-177. [CrossRef] [PubMed]

109. Li, C.; Miao, W.; Wentao, C.; Shuli, L.; Chenghao, Z.; Hongwei, Y.; Dongxiao, S.; Shengli, Z. Genetic Analyses Confirm SNPs in HSPA8 and ERBB2 are Associated with Milk Protein Concentration in Chinese Holstein Cattle. Genes 2019, 10, 104. [CrossRef] [PubMed]

110. Shi, L.; Liu, L.; Ma, Z.; Lv, X.; Li, C.; Xu, L.; Han, B.; Li, Y.; Zhao, F.; Yang, Y.; et al. Identification of genetic associations of ECHS 1 gene with milk fatty acid traits in dairy cattle. Anim. Genet. 2019, 50, 430-438. [CrossRef]

111. Li, M.; Qisong, G.; Mengqi, W.; Yan, L.; Yujia, S.; Zhi, C.; Huimin, Z.; Niel, A.K.; Zhangping, Y.; Yongjiang, M. Polymorphisms in Fatty Acid Desaturase 2 Gene Are Associated with Milk Production Traits in Chinese Holstein Cows. Animals 2020, $10,671$. [CrossRef]

112. Polasik, D.; Goli'nczak, J.; Proskura, W.; Terman, A.; Dybus, A. Association between THRSP Gene Polymorphism and Fatty Acid Composition in Milk of Dairy Cows. Animals 2021, 11, 1144. [CrossRef]

113. Rincón, G.; Islas-Trejo, A.; Castillo, A.R.; Bauman, D.E.; German, B.J.; Medrano, J.F. Polymorphisms in genes in the SREBP1 signalling pathway and SCD are associated with milk fatty acid composition in Holstein cattle. J. Dairy Res. 2012, 79, 66-75. [CrossRef] [PubMed]

114. Bhattarai, D.; Chen, X.; Rehman, Z.U.; Hao, X.; Ullah, F.; Dad, R.; Talpur, H.S.; Kadariya, I.; Cui, L.; Fan, M.; et al. Association of MAP4K4 gene single nucleotide polymorphism with mastitis and milk traits in Chinese Holstein cattle. J. Dairy Res. 2017, 84, 76-79. [CrossRef] [PubMed] 
115. Dux, M.; Magdalena, M.; Eulalia, S.; Dagmara, R.; Krzysztof, F.; Emilia, B.; Lech, Z. Association of SNP and STR polymor-phisms of insulin-like growth factor 2 receptor (IGF2R) gene with milk traits in Holstein-Friesian cows. J. Dairy Res. 2018, 85, 138-141. [CrossRef]

116. Selvaggi, M.; Claudia, C.; Francesca, C.; Sara, A.; Giulio, A.; Tufarelli, V.; Dario, C. Determination of a possible relationship between a single nucleotide polymorphism (SNP) in the promoter region of the SIRT1 gene and production and reproduction traits in the Ag-erolese cattle breed. Arch. Anim. Breed. 2019, 62, 107-112. [CrossRef] [PubMed]

117. Li, C.; Sun, D.; Zhang, S.; Yang, S.; Alim, M.A.; Zhang, Q.; Li, Y.; Liu, L. Genetic effects of FASN, PPARGC1A, ABCG2 and IGF1 revealing the association with milk fatty acids in a Chinese Holstein cattle population based on a post genome-wide association study. BMC Genet. 2016, 17, 110. [CrossRef]

118. Soltani-Ghombavani, M.; Ansari-Mahyari, S.; Rostami, M.; Ghanbari-Baghenoei, S.; Edriss, M. Effect of polymorphisms in the ABCG2, LEPR and SCD1 genes on milk production traits in Holstein cows. S. Afr. J. Anim. Sci. 2016, 46, 196. [CrossRef]

119. Tumino, S.; Criscione, A.; Moltisanti, V.; Marletta, D.; Bordonaro, S.; Avondo, M.; Valenti, B. Feeding System Resizes the Effects of DGAT1 Polymorphism on Milk Traits and Fatty Acids Composition in Modicana Cows. Animals 2021, 11, 1616. [CrossRef]

120. Shi, L.; Lin, L.; Xiaoqing, L.; Zhu, M.; Yuze, Y.; Yanhua, L.; Feng, Z.; Sun, D.; Han, B. Polymorphisms and genetic effects of PRLR, MOGAT1, MINPP1 and CHUK genes on milk fatty acid traits in Chinese Holstein. BMC Genet. 2019, 20, 69. [CrossRef] [PubMed]

121. Shi, L.; Liu, L.; Lv, X.; Ma, Z.; Li, C.; Li, Y.; Zhao, F.; Sun, D.; Han, B. Identification of genetic effects and potential causal polymorphisms of CPM gene impacting milk fatty acid traits in Chinese Holstein. Anim. Genet. 2020, 51, 491-501. [CrossRef]

122. Shi, L.; Han, B.; Lin, L.; Xiaoqing, L.; Zhu, M.; Li, C.; Lingna, X.; Li, Y.; Zhao, F.; Yang, Y.; et al. Determination of Genetic Effects of LIPK and LIPJ Genes on Milk Fatty Acids in Dairy Cattle. Genes 2019, 10, 86. [CrossRef]

123. Argov-Argaman, N.; Mida, K.; Cohen, B.-C.; Visker, M.; Hettinga, K. Milk Fat Content and DGAT1 Genotype Determine Lipid Composition of the Milk Fat Globule Membrane. PLoS ONE 2013, 8, e68707. [CrossRef] [PubMed]

124. Barbosa, D.S.; Sonstegars, M.; Thallman, S.; Connor, R.; Schnabel, E.; Van Tassell, C.P. Characterization of DGAT1 allelic effects in a sample of North American Holstein cattle. Anim. Biotechnol. 2010, 21, 88-99. [CrossRef] [PubMed]

125. Berry, D.P.; Howard, D.; O’Boyle, P.; Waters, S.; Kearney, J.; McCabe, M. Associations between the K232A polymorphism in the diacylglycerol-O-transferase 1 (DGAT1) gene and performance in Irish Holstein-Friesian dairy cattle. Ir. J. Agric. Food Res. 2010, $49,1-9$.

126. Hill, R.; Canal, A.; Bondioli, K.; Morell, R.; Garcia, M. Molecular markers located on the DGAT1, CAST, and LEPR genes and their associations with milk production and fertility traits in Holstein cattle. Genet. Mol. Res. 2016, 15. [CrossRef]

127. Bobbo, T.; Tiezzi, F.; Penasa, M.; De Marchi, M.; Cassandro, M. Short communication: Association analysis of diacylglycerol acyltransferase (DGAT1) mutation on chromosome 14 for milk yield and composition traits, somatic cell score, and coagulation properties in Holstein bulls. J. Dairy Sci. 2018, 101, 8087-8091. [CrossRef]

128. Bovenhuis, H.; Visker, W.; van Valenberg, H.J.F.; Buitenhuis, A.J.; van Arendonk, J.A.M. Effects of the DGAT1 polymorphism on test-day milk production traits throughout lactation. J. Dairy Sci. 2015, 98, 6572-6582. [CrossRef]

129. Kadlecova, V.; Nemeckova, D.; Jecminkova, K.; Stadnik, L. The effects of polymorphism in the dgat1 gene on energy balance and milk production traits in primiparous Holstein cows during the first six months of lactation. Bulg. J. Agric. Sci. 2014, 20, 203-209.

130. Komisarek, J.; Kolenda, M. The effect of DGAT1 polymorphism on milk production traits in dairy cows depending on environmental temperature. Turk. J. Vet. Anim. Sci. 2016, 40, 251-254. [CrossRef]

131. Lu, J.; Boeren, S.; van Hooijdonk, T.; Vervoort, J.; Hettinga, K. Effect of the DGAT1 K232A genotype of dairy cows on the milk metabolome and proteome. J. Dairy Sci. 2015, 98, 3460-3469. [CrossRef]

132. Pacheco-Pappenheim, S.; Yener, S.; Van Valenberg, H.J.; Tzompa-Sosa, D.A.; Bovenhuis, H. The DGAT1 K232A polymorphism and feeding modify milk fat triacylglycerol composition. J. Dairy Sci. 2019, 102, 6842-6852. [CrossRef] [PubMed]

133. Streit, M.; Neugebauer, N.; Meuwissen, T.; Bennewitz, J. Short communication: Evidence for a major gene by polygene interaction for milk production traits in German Holstein dairy cattle. J. Dairy Sci. 2011, 94, 1597-1600. [CrossRef]

134. Szyda, J.; Morek-Kopeć, M.; Komisarek, J.; Żarnecki, A. Evaluating markers in selected genes for association with functional longevity of dairy cattle. BMC Genet. 2011, 12, 30. [CrossRef]

135. Tabaran, A.-F.; Balteanu, V.A.; Gal, E.; Pusta, D.; Mihaiu, R.; Dan, S.D.; Mihaiu, M. Influence of DGAT1 K232A Polymorphism on Milk Fat Percentage and Fatty Acid Profiles in Romanian Holstein Cattle. Anim. Biotechnol. 2014, 26, 105-111. [CrossRef]

136. Tzompa-Sosa, D.A.; Van Valenberg, H.; Van Aken, G.; Bovenhuis, H. Milk fat triacylglycerols and their relations with milk fatty acid composition, DGAT1 K232A polymorphism, and milk production traits. J. Dairy Sci. 2016, 99, 3624-3631. [CrossRef] [PubMed]

137. van Gastelen, S.; Antunes-Fernandes, E.C.; Hettinga, K.A.; Dijkstra, J. The effect of linseed oil and DGAT1 K232A polymor-phism on the methane emission prediction potential of milk fatty acids. J. Dairy Sci. 2018, 101, 5599-5604. [CrossRef]

138. Krovvidi, S.; Thiruvenkadan, A.K.; Murali, N.; Saravanan, R.; Vinoo, R.; Metta, M. Evaluation of non-synonym mutation in DGAT1 K232A as a marker for milk production traits in Ongole cattle and Murrah buffalo from Southern India. Trop. Anim. Health Prod. 2021, 53, 118. [CrossRef]

139. Szewczuk, M. Association of a genetic marker at the bovine Janus kinase 2 locus (JAK2/RsaI) with milk production traits of four cattle breeds. J. Dairy Res. 2015, 82, 287-292. [CrossRef] [PubMed]

140. Liang, Y.; Qisong, G.; Qiang, Z.; Abdelaziz, A.; Li, M.; Zhangping, Y.; Niel, K.; Mao, Y. Polymorphisms of the ACSL1 Gene Influence Milk Production Traits and Somatic Cell Score in Chinese Holstein Cows. Animals 2020, 10, 2282. [CrossRef] 
141. Qin, Y.; Chen, S.; Song-Jia, L. Polymorphisms of Mitochondrial ATPASE 8/6 Genes and Association with Milk Production Traits in Holstein Cows. Anim. Biotechnol. 2012, 23, 204-212. [CrossRef]

142. Derakhshani, H.; Jan, P.; Jeroen, B.; Herman, B.; Ehsan, K.W. Association of bovine major histocompatibility complex (BoLA) gene polymorphism with colostrum and milk microbiota of dairy cows during the first week of lactation. Microbiome 2018, 6, 203. [CrossRef] [PubMed]

143. Rahmatalla, A.S.; Müller, U.; Strucken, E.M.; Reissmann, M.; Gudrun, A. BrockmannThe F279Y polymorphism of the GHR gene and its relation to milk production and somatic cell score in German Holstein dairy cattle. J. Appl. Genet. 2011, 52, 459-465. [CrossRef]

144. Sajjanar, B.; Deb, R.; Singh, U.; Kumar, S.; Brahmane, M.; Nirmale, A.; Bal, S.K.; Minhas, P.S. Identification of SNP inHSP90AB1and its Association with the Relative Thermotolerance and Milk Production Traits in Indian Dairy Cattle. Anim. Biotechnol. 2014, 26, 45-50. [CrossRef] [PubMed]

145. Cao, M.; Shi, L.; Peng, P.; Han, B.; Liu, L.; Lv, X.; Ma, Z.; Zhang, S.; Sun, D. Determination of genetic effects and functional SNPs of bovine HTR1B gene on milk fatty acid traits. BMC Genom. 2021, 22, 575. [CrossRef]

146. Bagnicka, E.; Siadkowska, E.; Strzałkowska, N.; Żelazowska, B.; Flisikowski, K.; Krzyżewski, J.; Zwierzchowski, L. Association of polymorphisms in exons 2 and 10 of the insulin-like growth factor 2 (IGF2) gene with milk production traits in Polish Holstein-Friesian cattle. J. Dairy Res. 2010, 77, 37-42. [CrossRef] [PubMed]

147. Berkowicz, E.W.; Magee, D.A.; Sikora, K.M.; Berry, D.P.; Howard, D.J.; Mullen, M.P.; Evans, R.D.; Spillane, C.; Machugh, D.E. Single nucleotide polymorphisms at the imprinted bovine insulin-like growth factor 2 (IGF2) locus are associated with dairy performance in Irish Holstein-Friesian cattle. J. Dairy Res. 2010, 78, 1-8. [CrossRef] [PubMed]

148. Clempson, M.M.; Pollott, G.E.; Brickell, J.; Wathes, D.C. Associations Between Bovine IGFBP2 Polymorphisms with Fertility, Milk Production, and Metabolic Status in UK Dairy Cows. Anim. Biotechnol. 2012, 23, 101-113. [CrossRef]

149. Yang, S.-H.; Bi, X.-J.; Xie, Y.; Li, C.; Zhang, S.-L.; Zhang, Q.; Sun, D.-X. Validation of PDE9A Gene Identified in GWAS Showing Strong Association with Milk Production Traits in Chinese Holstein. Int. J. Mol. Sci. 2015, 16, 26530-26542. [CrossRef]

150. Zheng, X.; Ju, Z.; Wang, J.; Li, Q.; Huang, J.; Zhang, A.; Zhong, J.; Wang, C. Single nucleotide polymorphisms, haplotypes and combined gen-otypes of LAP3 gene in bovine and their association with milk production traits. Mol. Biol. Rep. 2011, 38, 4053-4061. [CrossRef]

151. Han, B.; Yuan, Y.; Liang, R.; Li, Y.; Liu, L.; Sun, D. Genetic Effects of LPIN1 Polymorphisms on Milk Production Traits in Dairy Cattle. Genes 2019, 10, 265. [CrossRef]

152. Haruna, I.L.; Zhou, H.; Hickford, J.G.H. Variation in bovine leptin gene affects milk fatty acid composition in New Zealand Holstein Friesian $\times$ Jersey dairy cows. Arch. Anim. Breed. 2021, 64, 245-256. [CrossRef]

153. Wang, C.; Liu, M.; Li, Q.; Ju, Z.; Huang, J.; Li, J.; Wang, H.; Zhong, J. Three novel single-nucleotide polymorphisms of MBL1 gene in Chinese native cattle and their associations with milk performance traits. Vet. Immunol. Immunopathol. 2011, 139, 229-236. [CrossRef] [PubMed]

154. Zhao, L.Z.; Wang, C.F.; Li, Q.L.; Ju, Z.H.; Huang, J.M.; Li, J.B.; Zhong, J.F.; Zhang, J.B. Novel SNPs of the mannan-binding lectin 2 gene and their association with production traits in Chinese Holsteins. Genet. Mol. Res. 2012, 11, 3744-3754. [CrossRef] [PubMed]

155. Wang, X.; Peñagaricano, F.; Tal-Stein, R.; Lipkin, E.; Khatib, H. Short communication: Association of an OLR1 polymorphism with milk production traits in the Israeli Holstein population. J. Dairy Sci. 2012, 95, 1565-1567. [CrossRef] [PubMed]

156. Shi, L.; Xiaoqing, L.; Lin, L.; Yuze, Y.; Zhu, M.; Han, B.; Sun, D. A post-GWAS confirming effects of PRKG1 gene on milk fatty acids in a Chinese Holstein dairy population. BMC Genet. 2019, 20, 53. [CrossRef]

157. Nafikov, R.A.; Schoonmaker, J.P.; Korn, K.T.; Noack, K.; Garrick, D.J.; Koehler, K.J.; Minick-Bormann, J.; Reecy, J.M.; Spurlock, D.E.; Beitz, D.C. Sterol regulatory element binding transcription factor 1 (SREBF1) polymorphism and milk fatty acid composition. J. Dairy Sci. 2013, 96, 2605-2616. [CrossRef]

158. Lv, Y.; Wei, C.; Zhang, L.; Lu, G.; Liu, K.; Du, L. Association Between Polymorphisms in the SLC27A1 Gene and Milk Pro-duction Traits in Chinese Holstein Cattle. Anim. Biotechnol. 2011, 22, 1-6. [CrossRef]

159. Nafikov, A.R.; Schoonmaker, P.J.; Korn, T.K.; Noack, K.; Garrick, J.D.; Koehler, K.J.; Minick-Bormann, J.; Reecy, J.M.; Spurlock, D.E.; Beitz, D.C. Association of polymorphisms in solute carrier family 27, isoform A6(SLC27A6) and fatty acid-binding protein-3 and fatty acid-binding protein-4 (FABP3 and FABP4) with fatty acid composition of bovine milk. J. Dairy Sci. 2013, 96, 6007-6021. [CrossRef]

160. Wang, M.; Song, H.; Zhu, X.; Xing, S.; Zhang, M.; Zhang, H.; Wang, X.; Yang, Z.; Ding, X.; Karrow, N.A.; et al. Toll-like receptor 4 gene polymorphisms influence milk production traits in Chinese Holstein cows. J. Dairy Res. 2018, 85, 407-411. [CrossRef]

161. Zhou, H.; Cheng, L.; Gong, H.; Byun, S.O.; Edwards, G.R.; Hickford, J.G.H. Variation in the Toll-like Receptor 4 (TLR4) gene affects milk traits in dairy cows. J. Dairy Res. 2017, 84, 426-429. [CrossRef]

162. Mao, Y.; Zhu, X.; Xing, S.; Zhang, M.; Zhang, H.; Wang, X.; Karrow, N.; Yang, L.; Yang, Z. Polymorphisms in the promoter region of the bovine lactoferrin gene influence milk somatic cell score and milk production traits in Chinese Holstein cows. Res. Vet. Sci. 2015, 103, 107-112. [CrossRef] [PubMed]

163. Ju, Z.; Li, Q.; Huang, J.; Hou, M.; Li, R.; Li, J.; Zhong, J.; Wang, C. Three novel SNPs of the bovine Tf gene in Chinese native cattle and their associations with milk production traits. Genet. Mol. Res. 2011, 10, 340-352. [CrossRef] [PubMed] 
164. Zwierzchowski, L.; Ostrowska, M.; Żelazowska, B.; Bagnicka, E. Single nucleotide polymorphisms in the bovine SLC2A12 and SLC5A1 glucose transporter genes-The effect on gene expression and milk traits of Holstein Friesian cows. Anim. Biotechnol. 2021, 1-11. [CrossRef] [PubMed]

165. Dar, M.R.; Singh, M.; Thakur, S.; Verma, A. Exploring the relationship between polymorphisms of leptin and IGF-1 genes with milk yield in indicine and taurine crossbred cows. Trop. Anim. Health Prod. 2021, 53, 1-8. [CrossRef]

166. Ostrowska, M.; Zwierzchowski, L.; Brzozowska, P.; Kawecka-Grochocka, E.; Żelazowska, B.; Bagnicka, E. The effect of single nucleotide polymorphism in the promoter region of bovine alpha-lactalbumin (LALBA) gene on LALBA expression in milk cells and milk traits of cows. J. Anim. Sci. 2021, 99, skab169. [CrossRef] [PubMed]

167. Bordonaro, S.; Tumino, S.; Donata, M.; Anna, D.; Fortunato, D.P.; Avondo, M.; Valenti, B. Effect of GH p.L127V Polymorphism and Feeding Systems on Milk Production Traits and Fatty Acid Composition in Modicana Cows. Animals 2020, 10, 1651. [CrossRef]

168. Friedrich, J.; Brand, B.; Ponsuksili, S.; Graunke, K.L.; Langbein, J.; Knaust, J.; Kühn, C.; Schwerin, M. Detection of genetic variants affecting cattle behaviour and their impact on milk production: A genome-wide association study. Anim. Genet. 2016, 47, 12-18. [CrossRef]

169. Wang, H.; Jiang, L.; Wang, W.; Zhang, S.; Yin, Z.; Zhang, Q.; Liu, J.-F. Associations between variants of the HALgene and milk production traits in Chinese Holstein cows. BMC Genet. 2014, 15, 125. [CrossRef]

170. Li, C.; Cai, W.; Liu, S.; Zhou, C.; Cao, M.; Yin, H.; Sun, D.; Zhang, S.; Loor, J.J. Association of UDP-galactose-4-epimerase with milk protein concentration in the Chinese Holstein population. Asian-Australas. J. Anim. Sci. 2020, 33, 1725-1731. [CrossRef] 